\title{
Review \\ Considerations for Cannabinoids in Perioperative Care by Anesthesiologists
}

\author{
Krzysztof Laudanski ${ }^{1, *(D)}$ and Justin Wain ${ }^{2, *}$ \\ 1 Department of Anesthesiology and Critical Care, University of Pennsylvania, Philadelphia, PA 19104, USA \\ 2 School of Osteopathic Medicine, Campbell University, Buies Creek, NC 27506, USA \\ * Correspondence: klaudanski@gmail.com (K.L.); jdwain1125@email.campbell.edu (J.W.)
}

Citation: Laudanski, K.; Wain, J. Considerations for Cannabinoids in Perioperative Care by Anesthesiologists. J. Clin. Med. 2022, 11, 558. https://doi.org/10.3390/ jcm11030558

Academic Editor: Patrice Forget

Received: 20 December 2021

Accepted: 18 January 2022

Published: 22 January 2022

Publisher's Note: MDPI stays neutral with regard to jurisdictional claims in published maps and institutional affiliations.

Copyright: (C) 2022 by the authors. Licensee MDPI, Basel, Switzerland. This article is an open access article distributed under the terms and conditions of the Creative Commons Attribution (CC BY) license (https:// creativecommons.org/licenses/by/ $4.0 /$ )

\begin{abstract}
Increased usage of recreational and medically indicated cannabinoid compounds has been an undeniable reality for anesthesiologists in recent years. These compounds' complicated pharmacology, composition, and biological effects result in challenging issues for anesthesiologists during different phases of perioperative care. Here, we review the existing formulation of cannabinoids and their biological activity to put them into the context of the anesthesia plan execution. Perioperative considerations should include a way to gauge the patient's intake of cannabinoids, the ability to gain consent properly, and vigilance to the increased risk of pulmonary and airway problems. Intraoperative management in individuals with cannabinoid use is complicated by the effects cannabinoids have on general anesthetics and depth of anesthesia monitoring while simultaneously increasing the potential occurrence of intraoperative hemodynamic instability. Postoperative planning should involve higher vigilance to the risk of postoperative strokes and acute coronary syndromes. However, most of the data are not up to date, rending definite conclusions on the importance of perioperative cannabinoid intake on anesthesia management difficult.
\end{abstract}

Keywords: cannabinoids; anesthesia; cannabidiol; tetrahydrocannabinol; neocannabinoids; perioperative management; review; human

\section{Introduction}

Cannabinoids are defined as chemicals found in the Cannabis sativa plant, with tetrahydrocannabinol (THC) and cannabidiol (CBD) being the most mentioned compounds [1,2]. There are over 60 other naturally occurring cannabinoids [1-6]. Other plants such as Echinacea purpurea, Echinacea angustifolia, Acmella oleracea, Helichrysum umbraculigerum, Radula marginate and Kava contain lipophilic alkyl amides, which are considered cannabinoids based on their chemical structure resemblance and their ability to interact with cannabinoid receptors $[7,8]$. Finally, synthetic (neocannabinoids) and endogenous cannabinoid compounds are also known $[9,10]$.

Structurally, cannabinoids resemble lipids, as all cannabinoids belong to the terpenes class [2-4]. These compounds are derivatives of the 5-carbon compound isoprene and constitute over 30,000 chemicals with common formula $\left(\mathrm{C}_{5} \mathrm{H}_{8}\right)_{n}$ [2]. Cannabinoids and terpenes are responsible for a plant's smell, ultraviolet protection, color, and structural support [4]. However, they are of increased interest because they possess several unique pharmacological properties $[1,2,4,11-15]$. These pharmacological potentials have been utilized in several ways, with recreational use comprising the majority of cannabinoid consumption $[2,4,12,16,17]$. FDA-approved indications for cannabinoid treatment include seizures, nausea, cancer pain, and certain neurological conditions [18-20]. Off-label medical treatments utilizing cannabinoids include treatments for headaches, schizophrenia, chronic pain, dementia, post-traumatic stress disorders, and many other conditions [21-24]. The increased presence of cannabinoids is of obvious concern for anesthesiologists, as more patients will likely consume them in increasing doses, potentially affecting anesthesia planning and execution. 
This rising abundance of cannabinoid usage in the general public is somewhat juxtaposed by difficult access to reliable, evidence-based, up-to-date information about their clinical actions and properties [25]. One should appreciate a yin and yang approach to cannabinoids, considering the many different aspects of their narrative. Cannabinoids often exhibit opposite actions depending on the exact compound studied, their enantiomers, species used to study the compound, or overall health status [26-30]. Their social acceptance and legal approval vary greatly $[25,31,32]$. The scientific opinions about the use and danger of opioids often juxtapose one another, while the robust clinical evidence is frequently dated to the time before the "War on Drugs" was initiated in the 1980s [12,14,25,26,33,34]. There are also a significant number of claims in the media that are difficult to validate but influence patients' consumption of cannabinoid products [17,19,25,35-38]. Patients often consume cannabinoids regardless of their efficacy [39,40]. Other confounding variables affecting the assessment of cannabinoid properties are the lack of compound standardization and the increasing variability in their strength and composition $[17,19,35,36]$. Frequently, natural cannabinoids are laced with other illicit substances causing modifications of their effects with significant clinical consequences [17,41,42].

The primary use of natural cannabinoids is centered around recreational and illicit use [2,17]. Neocannabinoids are frequently added as adulterators or potentiators to natural cannabinoid preparations $[9,10,17,43]$. Illicit or recreational marijuana use often affects individuals from disadvantaged backgrounds, thus adding to their illness burden while interacting with their primary treatment $[24,38,44-46]$. Finally, cannabinoid-based compounds are becoming more commonly approved and regulated in drugs such as Nabilone (Cesamet $^{\mathrm{TM}}$ ), Cannabidiol (Epidiolex ${ }^{\mathrm{TM}}$ ), Nabiximols (Sativex ${ }^{\mathrm{TM}}$ ), Dronabinol (Marinol ${ }^{\mathrm{TM}}$, Adversa $^{\mathrm{TM}}$, Syndros ${ }^{\mathrm{TM}}$, and Reduvo ${ }^{\mathrm{TM}}$ ), and Rimonabant/SR141716 (Acomplia ${ }^{\mathrm{TM}}$ and Zimulti $^{\mathrm{TM}}$ [ [47-50].

Considering the complexity of the information about these compounds, an average anesthesia provider may find him/herself in need of a comprehensive synthesis of information pertaining to the execution of an anesthesia plan. Unfortunately, though prior reviews exist, they are often short in scope, noncomprehensive, frequently citing somewhat limited literature, focused on a specific population, or addressing a specific audience [51-53].

For the scope of this paper, we will focus on the possible effects of cannabinoids on the formulation of perioperative care in the adult population. For simplicity, we decided to use cannabinoids as the word covering all types of marijuana derivatives and similar synthetic structures unless specified otherwise in the text. This review aims to provide the reader with a comprehensive review of the potential ways cannabinoids and their derivatives may affect anesthesia planning and execution.

\section{Types of Cannabinoids}

Cannabinoids can be grouped as synthetic, endogenous, or natural [2,4,54] (Figure 1). Natural cannabinoids are referenced to tetrahydrocannabinol (THC) as the standard, though multiple isomers having the same chemical formula exist $\left(\mathrm{C}_{21} \mathrm{H}_{30} \mathrm{O}_{2}\right)[1,3,29]$. The standard that all cannabinoids are referenced to is (-)-trans- $\Delta$ 9-tetrahydrocannabinol (9-THC), the most potent psychoactive isomer [4]. On the other hand, (-)-trans- $\Delta 8$ tetrahydrocannabinol (8-THC) and hydroxylation products of both 8-THC and 9-THC, demonstrated decreasing psychoactive potency [3,55-58]. The focus on the psychoactive action of 9-THC led to the labeling of other cannabinoids as inert if they did not exhibit psychoactive activity. However, this is a misleading term, as psychoactive properties are not the only desirable trait, even if they are the most popular trait of these compounds. Several inert cannabinoids have not been characterized in depth despite interesting pharmacology $[4,6,9,11,54,59]$. To add to the complexity of the presented landscape, cannabinoids can be synthesized de novo $[10,43]$. These cannabinoids produced in the lab are called neocannabinoids $[9,10,42,43]$. To distinguish them from lab-originating THC, the term neocannabinoids is used [9]. 


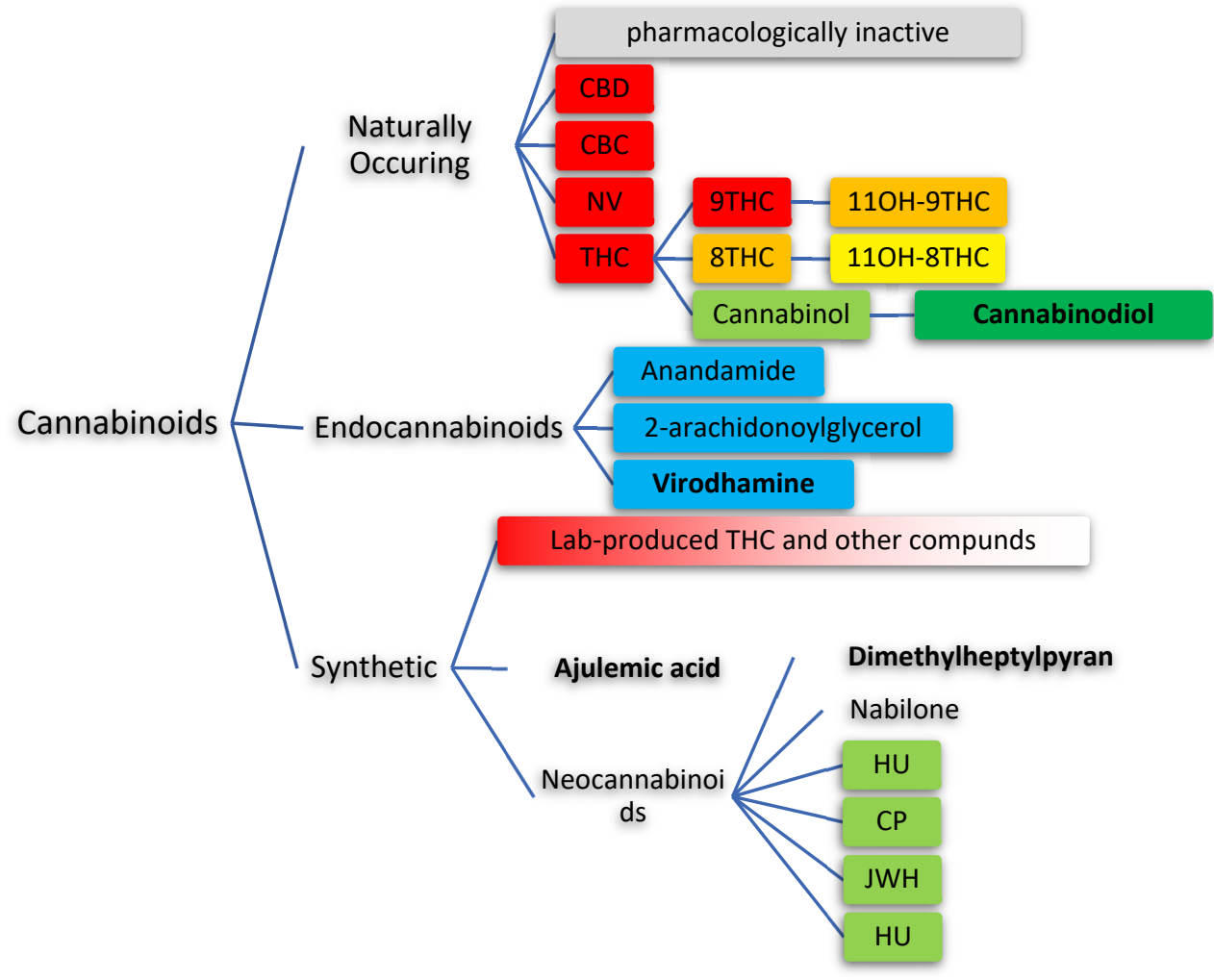

Figure 1. Division of cannabinoids depending on the source with color-coded psychoactive potency (red: most present, yellow: less present, green: not present; blue: endocannabinoids).

\section{Utilization of Cannabinoids}

According to the National Survey on Drug Use and Health conducted in the USA in 2019, 48.2 million people ages 12 and up were marijuana users. 3.3 million were between ages 12 and 17, 12 million were between ages 18 and 25, and 33 million were aged 26 or older, according to the official tally [60]. Marijuana remains the most common illicit substance in the USA. Marijuana consumption increased by $6.5 \%$ from 2002 to 2019 , especially in states that legalized the use of marijuana $[16,17]$. Neocannabinoids, synthetic analogs of naturally occurring cannabinoids, are used by individuals between 20 and 40 years old, especially in cases of fatal overdose [42,43].

These numbers are probably underestimated, as consumption of cannabinoids is frequently penalized and only recently significantly increased, following decriminalization in law and social acceptance [61]. Social acceptance varies by country and by state within the USA based on the rates of use within the population [33]. In the USA, recreational cannabinoids have become legalized in 18 states since 2012. This increased consumption drove the increased incidence of side effects $[3,62,63]$. Worldwide, several countries no longer penalize marijuana or cannabinoid consumption while others maintain cannabis compounds as illegal compounds [58]. In addition, higher concentrations of cannabinoid psychoactive compounds further complicate recreational and illicit use compared to the prior century [18-20]. As mentioned earlier, legal and societal background determines the likelihood that anesthesiologists will encounter individuals consuming cannabinoids for various reasons $[12,28,37,38,64]$. However, the increased prevalence of cannabinoid compounds is such that accidental intake has been reported in all ages, including newborns [65-68]. Intake of cannabinoids from FDA-approved medication remains a minuscule proportion of cannabis intake by the general population [47-50].

\section{Source of Cannabinoids}

Cannabinoids are natural compounds extracted from the Cannabis sativa plant, with flowers, buds, leaves, and stems being utilized to produce active compounds. Depending 
on the concentration of 9-THC, the plant is classified as hemp (below $0.3 \%$ ), while a higher concentration is labeled as marijuana. This is an important distinction, as hemp is legal in the USA while marijuana depends on local state and federal regulation [33].

Several formulations of cannabinoids exist. Dry leaves are one way to consume, but the more refined products, inhaled psychoactive compounds, come from Cannabis sativa. These products are divided into solvent and solvent-free formulations. Solventless concentrates include kief, hash, rosin, bubble hash, distillates, and isolates with increasing 9THC content. Hashish is a resin from the Cannabis sativa plant with a higher concentration of psychoactive compounds (3-52.9\%) [31,35,36]. The solvent-based formulation uses a hydrophobic solvent to extract 9-THC and similar compounds. Hash oil is an oleoresin obtained from cannabinoids or hashish and contains up to $\sim 45 \%$ of 9-THC $[31,35,36]$. CBD oil is divided according to 9-THC concentration [69]. Some claim that hemp oil should not contain cannabinoids because it is produced for mass consumption, yet testing for 9-THC is not routinely performed [30].

The preferable route for cannabinoid intake is oral, followed by inhalation, with intravenous intake being the least frequently used [1,3,70-73].

It is also increasingly likely that FDA-approved compounds with derivatives of cannabinoids will become more prevalent in the general population, especially in individuals with complicated and complex diseases, as most of these medications are not the first line of treatment $[22,48,55,74]$. They include Cesamet ${ }^{\mathrm{TM}}$, Epidiolex ${ }^{\mathrm{TM}}$, Sativex ${ }^{\mathrm{TM}}$,

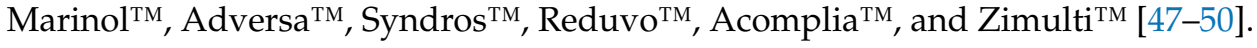

\section{Natural Synthesis of Cannabinoids}

Several routes exist for natural cannabinoids to be synthesized and metabolized (Table 1). In general, they undergo a synthesis from a precursor using specific synthetases, followed by hydroxylation, carboxylation, and glucuronidation $[75,76]$.

Cannabigerolic acid (CBGA), an acidic form of cannabigerol (CBG), is the precursor of (-)-trans- $\Delta^{9}$-tetrahydrocannabinol, or cannabidiol (CBD) $[14,19]$. Consequently, there is a reverse relationship between the concentrations of 9-THC and CBD in natural compounds [19]. This opposition between 9-THC and CBD is one example of a yin and yang effect in the cannabinoid world, as they seem to have opposite effects $[19,77,78]$. CBD has no psychoactive effect and interferes with 9-THC at the cannabinoid receptor and metabolism level [79]. However, due to the pressures from illegal manufacturers and criminal activities, there is an increase in the active compound of 9-THC and a decrease in CBD, resulting in increased potency of preparations $[19,20]$. THC also undergoes a natural transformation into cannabinol (CBN) devoid of psychoactive potency [80]. CBD can be cyclized into 9-THC and 8-THC during pyrolysis [58,81-83]. In addition, one must keep in mind that pyretic transformation of cannabinoids yields several hundred compounds, similar to smoking nicotine-based products or THC [82].

Under the nominal condition, 9-THC is converted into 11-hydroxy- $\Delta^{9} \mathrm{THC}(11-\mathrm{OH}-$ THC), which is less potent than 9-THC [76]. However, if 9-THC is taken orally, more 11-OH-THC may be delivered after the transformation of 9-THC into this metabolite [76]. In addition, 9-THC can also break down into CBN, a nonpsychoactive metabolite [84].

Cannabichromene (CBC) is a naturally occurring, nonactive phytocannabinoid with unknown endogenous activity [85]. Cannabicitran (CBT) and cannabidivarin (CBDV) are phytocannabinoids with inconsistently described receptor affinity, metabolism, and natural biological activity [86-88]. 
Table 1. Naturally and artificially synthesized cannabinoids and their main biological effects. Additionally included are the specific cannabinoid receptor and type of receptor which are utilized.

\begin{tabular}{|c|c|c|c|c|}
\hline Cannabinoid & $\begin{array}{c}\text { Predominant } \\
\text { Receptor(s) }\end{array}$ & Type(s) of Binding & Dominant Effects in Humans & Ref. \\
\hline$\triangle 9-\mathrm{THC}$ & $\mathrm{CB} 1, \mathrm{CB} 2$ & Partial agonist & Psychotropic effect, appetite, analgesia & {$[75]$} \\
\hline$\triangle 8-\mathrm{THC}$ & $\mathrm{CB} 1, \mathrm{CB} 2$ & Partial agonist & Psychotropic effect, appetite, analgesia & {$[58,75]$} \\
\hline Cannabidiol (CBD) & $\mathrm{CB} 1, \mathrm{CB} 2, \alpha_{2}, 5-\mathrm{HT}_{1 \mathrm{~A}}$ & Agonist & $\begin{array}{l}\text { anti-inflammatory, analgesic, } \\
\text { antianxiety, antitumor }\end{array}$ & {$[49,75,89]$} \\
\hline Cannabinol (CBN) & $\mathrm{CB} 1, \mathrm{CB} 2$ & $\begin{array}{l}\text { Partial agonist, } \\
\text { antagonist }\end{array}$ & $\begin{array}{l}\text { Immune suppression, } \\
\text { seizure suppression }\end{array}$ & {$[49,75,89-92]$} \\
\hline $\begin{array}{l}\text { Cannabichromene } \\
\text { (CBC) }\end{array}$ & TRPV1, CB2 & Agonist & Antinociceptive, anti-inflammatory & [85] \\
\hline Cannabicitran (CBT) & $\mathrm{CB} 1 ?, \mathrm{CB} 2 ?$ & Unclear & Poorly defined & [75] \\
\hline $\begin{array}{c}\text { Cannabidivarin } \\
(\mathrm{CBDV})\end{array}$ & $\mathrm{CB} 1, \mathrm{CB} 2$ & Antagonist & Antipsychotic effect of metabolites & {$[75,93]$} \\
\hline $\begin{array}{l}\text { Cannabigerol (CBG) } \\
\text { Nabilone }\end{array}$ & $\mathrm{CB} 1, \alpha_{2}, 5-\mathrm{HT}_{1 \mathrm{~A}}$ & $\begin{array}{c}\text { Antagonist, agonist } \\
\text { Agonist }\end{array}$ & Antitumor activity, poorly defined & $\begin{array}{c}{[94]} \\
{[2195-1011}\end{array}$ \\
\hline Nabiximols & $\mathrm{CB} 1, \mathrm{CB} 2$ & Partial Agonist & $\begin{array}{l}\text { Alleviating symptoms of dry mucosa } \\
\text { in multiple sclerosis }\end{array}$ & {$[47,102]$} \\
\hline Dronabinol & $\mathrm{CB} 1, \mathrm{CB} 2$ & Partial Agonist & Appetite stimulation & [103-107] \\
\hline Rimonabant/SR141716 & CB1 & Antagonist & $\begin{array}{l}\text { Appetite inhibition, seizure } \\
\text { threshold, psychoactive }\end{array}$ & {$[50,108,109]$} \\
\hline
\end{tabular}

\section{FDA-Approved Cannabinoid Formulation}

Four cannabinoid medications were approved for use in the USA by the FDA, but one regulatory permit has been withdrawn [110] (Table 1).

Dronabinol (Marinol ${ }^{\mathrm{TM}}$, Adversa ${ }^{\mathrm{TM}}$, Syndros ${ }^{\mathrm{TM}}$, and Reduvo ${ }^{\mathrm{TM}}$ ) is an FDA-approved drug that is a synthetic THC prepared in $2.5 \mathrm{mg}, 5 \mathrm{mg}$, or $10 \mathrm{mg}$. Dronabinol is effective as a partial agonist of cannabinoid receptors $\mathrm{CB} 1$ and CB2. It is used as an appetite stimulant and was tested as a treatment for AIDS- and cancer-related anorexia [103,104]. After a six-week study, patients using the drug showed significant improvement in appetite and the drug is now widely used for anorexia/weight gain disorders [103,104,107]. Another study was held to compare the effectiveness of cannabis extract (CE) instead of delta-9tetrahydrocannabinol (9-THC) as opposed to a placebo. In this study, 164 patients were treated with $1 \mathrm{mg}$ of cannabidiol, $2.5 \mathrm{mg}$ of THC, or a placebo by mouth for six weeks. An independent review board concluded that there was an insufficient difference between compounds [105]. Some suggest that the drug may be effective in obstructive sleep apnea, but no definite follow-up study was conducted after the initial report [106,107]. Marinol was tested for drug interactions with cytotoxic agents, anti-infective agents, sedatives, and opioid analgesics without showing any significant interactive events.

Cannabidiol (Epidiolex ${ }^{\mathrm{TM}}$ ) has concentrated cannabidiol $(100 \mathrm{mg} / \mathrm{mL})$ and is used to treat seizures in infantile patients with Dravet Syndrome and Lennox-Gastaut syndrome $[49,89]$. CYP3A4 and CYP2C19 metabolize Epidiolex ${ }^{\mathrm{TM}}$, but the specific mechanism of action which makes cannabidiol an anticonvulsive agent is unknown [49]. Because of this, coadministration with strong CYP3A4 or CYP2C19 inhibitors will increase cannabidiol plasma concentrations, while coadministration with strong CYP3A4 and CYP2C19 inducers will decrease cannabidiol plasma concentrations, both leading to possible adverse effects or drug inefficiency. Like most antiepileptic medications, cannabidiol should not be stopped abruptly. In addition, some reports suggest an increased incidence of pulmonary infection secondary to CB2 interaction and immunosuppression [90-92].

Nabiximols (Sativex ${ }^{\mathrm{TM}}$ ) is a combination drug delivering a dose of $2.7 \mathrm{mg}$ THC and $2.5 \mathrm{mg}$ CBD with each spray and is approved to treat dry mucosa in patients with multiple sclerosis $[102,111]$. Some have suggested using the drug to manage chronic pain, but the medication did not meet this goal [112]. Nabiximols (Sativex ${ }^{\mathrm{TM}}$ ) has a good safety profile, with drowsiness and dizziness being the most common side effects. 
Nabilone (Cesamet ${ }^{\mathrm{TM}}$ ) is a synthetic cannabinoid mimicking THC. It has been approved to treat neuropathic and other types of pain, but its impact is relatively small $[99,100,113]$. Consequently, nabilone is utilized as a pain adjunct. A clinical trial demonstrated its effectiveness against chemotherapy-related nausea in certain regiments $[97,101,114]$. The expanding indications of nabilone may include Alzheimer's disease, Parkinson's disease, and inflammatory bowel disease in the future $[92,95,115]$. Nabilone can stimulate appetite during treatment with $0.5 \mathrm{mg}$ nabilone/ 2 weeks followed by $1.0 \mathrm{mg}$ nabilone/ 6 weeks, with a subsequent increase in caloric intake of $342 \mathrm{kcal}$ and an increased carbohydrate intake of $64 \mathrm{~g}$ [101]. The most common side effects mimic THC's and include euphoria and dizziness $[100,101]$. No comparison to dronabinol effectiveness in terms of appetite stimulation is available.

Rimonabant/SR141716 (Acomplia ${ }^{\mathrm{TM}}$ and Zimulti ${ }^{\mathrm{TM}}$ ) is the only CB1 receptor antagonist. It was briefly approved as an antiobesity medication, but it was withdrawn due to serious side effects, including psychosis. Currently, this active compound has only experimental application [108].

\section{Mechanism of Action}

Several receptors for cannabinoids exist (Table 2) [116].

Table 2. Cannabinoid receptors, agonists, locations, and actions in humans.

\begin{tabular}{|c|c|c|c|c|}
\hline Receptor & Ligands & $\begin{array}{l}\text { Dominant } \\
\text { Location }\end{array}$ & $\begin{array}{l}\text { Dominant } \\
\text { Action }\end{array}$ & Ref. \\
\hline CB1 & $\begin{array}{l}\text { Anandamide, THC } \\
\text { 2-AG, 2-AGE, } \\
\text { SR141716 }\end{array}$ & CNS & Pain, memory, energy metabolism & {$[88,108,116-124]$} \\
\hline CB2 & $\begin{array}{l}\text { Anandamide, THC } \\
\text { 2-AG, CBDV }\end{array}$ & CNS, immune cells & Immune signaling, inflammatory responses & {$[93,116,125,126]$} \\
\hline A2 & Norepinephrine, CBG & CNS & $\begin{array}{l}\text { Central sympathectomy, vasodilatory, } \\
\text { antianxiolytic effects }\end{array}$ & {$[14,127-131]$} \\
\hline $5-\mathrm{HT}_{1 \mathrm{~A}}$ & Serotonin, CBD & CNS, platelets & Mood, platelet activation, antinausea & {$[94,132,133]$} \\
\hline TRPV & $\begin{array}{l}\text { Anandamide, CBC, } \\
\text { ODA, NADA }\end{array}$ & PNS & Pain, inflammation modulation, vascular tone & {$[120,134-143]$} \\
\hline GLYR & Glycine, THC & CNS & $\begin{array}{c}\text { Motor control, pain, synaptic } \\
\text { neurotransmission, dependence, cholesterol } \\
\text { membrane metabolism }\end{array}$ & [144-148] \\
\hline
\end{tabular}

The two main cannabinoid receptors are cannabinoid receptor 1 (CB1) and cannabinoid receptor 2 (CB2), both of which are G-protein-coupled receptors (GPCR) on the cell surface $[117,149]$.

The human CB1 receptor is encoded by the CNR1 gene and consists of 472 amino acids [124]. The CB1 receptor is also found in rats and mice and consists of 473 amino acids with 97-99\% amino acid sequence identity to humans, suggesting high structural homology. CB1 receptors are most abundant in the central nervous system, specifically in the cortex, hippocampus, basal ganglia, and cerebellum, contributing to cannabinoids' effects on memory, cognition, movement, and nociception [150,151]. In addition, CB1 receptors are found in the intestine, liver, pancreas, immune system, heart, vascular system, and reproductive system but at lower receptor density [151]. CB1 receptors can also form homo- and heterodimers with other CB1 receptors and GPCRs to modulate receptor signaling [124]. Various neural functions have been suppressed in CB1 knock-out mice or the presence of a CB1 antagonist (SR141716A). Specifically, blocking the CB1 endocannabinoid receptor can suppress appetite and feeding behaviors [150], the extinction of aversive memories, cerebellum-dependent discrete motor learning, drug addiction, and neuroprotection following closed head injuries [123,150,152,153].

The human CB2 receptor is encoded by the CNR2 gene and consists of 360 amino acids, sharing only $44 \%$ sequence homology to the CB1 receptor at the protein level. The 
$\mathrm{CB} 2$ receptor also shows greater variation amongst different species when compared to the CB1 receptor. The amino acid sequence homology of the CB2 receptor among humans and rodents is just above $80 \%$ [154]. CB2 receptors are most abundant on immune cells, specifically B-cells and natural killer $(\mathrm{NK})$ cells, where stimulation of these receptors can modulate immune function [155]. Less pronounced receptor densities of CB2 are found in the adrenal gland, lung, myocardium, vascular smooth muscle, testis, prostate, bone, and some tumors [151,155]. CB2 receptors are particularly important for immune system function, specifically B-cells and natural killer (NK) cells [150]. They also play a role in seizure threshold and behavioral regulation [156].

THC serves as a partial agonist for CB1 and CB2. Endocannabinoids, which are lipid chemicals synthesized by humans and animals, serve as agonists and antagonists for the CB1 and CB2 receptors $[150,151,154,157]$. Common endocannabinoids that function as agonists are arachidonoylethanolamide (AEA) and 2-arachidonoylglycerol (2-AG), while common antagonists are sphingosine and desmopressin. When THC binds, a conformational change occurs in the transmembrane receptor, causing an interaction with the G-protein, allowing the release of guanosine diphosphate (GDP) from the G $\alpha$ i-sub-unit followed by the binding of guanosine triphosphate (GTP). The binding of GTP causes the activation of the G-protein, allowing the GTP-ai subunit to dissociate from the betagamma unit. The GTP-ai subunit inhibits adenylate cyclase, resulting in a decrease in cyclic adenosine monophosphate (cAMP) and subsequently lowering intracellular $\mathrm{Ca}^{2+}$ concentrations [79]. Compared to THC, CBD also acts as a partial agonist, but its binding to $\mathrm{CB} 1$ and $\mathrm{CB} 2$ is relatively weak. There is also significant dimerization between CB1 and $\mathrm{CB} 2$, resulting in different activation patterns depending on the agonist type, resulting in differential activation of G-couple protein, MAPK, and $\beta$-arrestin [158].

Studies have shown that CBD can bind to the serotoninergic $5-\mathrm{HT}_{1 \mathrm{~A}}$ receptor (5$\mathrm{HT}_{1 \mathrm{~A}}$ ) and opioid receptors, specifically the $\mu$-opioid receptor (MOR) and $\delta$-opioid receptor (DOR), which all function similarly to the cannabinoid receptors in their inhibition of adenylate cyclase [157]. The interaction with 5-hydroxytryptamine $\left(5-\mathrm{HT}_{1 \mathrm{~A}}\right)$ is another potential interaction with cannabis compounds. These interactions with the receptor in basal ganglia may be responsible for a potentially beneficial effect on motor function in some neurodegenerative motor disorders [13,14,159]. Similar interaction in striate may result in the antinausea and antivomiting effect of the cannabinoids [55,133,160]. The agonistic effect of 5- $\mathrm{HT}_{1 \mathrm{~A}}$ located on the ventral medial prefrontal cortex may modulate the antidepressant effect of cannabinoids, but CB1 is often required to work synergistically to attain antianxiolytic antidepressant effects [132,161,162].

The TRPV receptor, capsaicin, and the vanilloid receptor are encoded by the TRPV gene and are involved in temperature regulation and pain sensation [134-138]. They have also been linked to decreasing the ability to make new memories by depressing long-term potentiation (LTP). Capsaicin is an agonist for this receptor used in most experimental studies [163]. Cannabinoid ligands acting via CB1 and TRPV1 can suppress inflammation and are particularly important for the performance of the endogenous cannabinoid system $[120,141]$.

Some studies demonstrate cannabinoids interacting with alpha two receptors [14]. This interaction is linked to vasodilatory and antianxiolytic effects [127-129]. In addition, experimental data suggest the involvement of this receptor in cannabinoids' anticonvulsant activity [130].

One should also be aware that other components of cannabinoids may exercise metabolic activity. For example, $\beta$-Myrcene is the most found terpene in modern Cannabis chemovars in the USA and is linked to sedation after intake [54,164,165]. In addition, $\alpha$-pinen inhibits acetylcholinesterase and may be responsible for intoxication [166,167]. 


\section{Pharmacodynamics and Pharmacokinetics}

The absorption of cannabinoids can vary based on the route of administration. A rapid increase in the serum level of cannabinoids and the penetration into the brain are key components of the drug's abusive potential.

Administering through inhalation or vaporization allows for rapid delivery into the bloodstream, causing THC and CBD plasma concentrations to peak within 3-10 $\mathrm{min}[76,168]$. Following inhalation, the bioavailability of THC ranges from 10 to $85 \%$, while the bioavailability of CBD averages $31 \%$, both of which are dependent on inter- and intrasubject inhalation characteristics (number of puffs, the smoke volume, and amount of time smoke is held inside the lungs) [76,169]. Furthermore, pyrolysis may occur during smoking and vaping, resulting in CBD to THC conversion $[81,83]$. Smoking results in inhalation of combustion products similar to the mechanisms seen during tobacco consumption, but the significance of this is unclear $[170,171]$. Theoretically, vaping results in a rapid increase in THC without additional side effects related to smoking [172]. However, vaping risk factors were recently appreciated $[29,173]$. Injecting cannabinoids generated the fastest and highest peak, but it is uncommon [73,76]. Injecting cannabinoids may result in endocarditis and other infectious diseases, but this is highly unlikely, as the intravenous route is negligible for these compounds. THC and CBD have a bioavailability of roughly $6 \%$ when orally administered due to their lipophilic structures, variable gut absorption, and extensive hepatic first-pass metabolism, with plasma concentrations within the pharmacodynamics therapeutic range for 2 to $6 \mathrm{~h}[76,79,168,174,175]$. The sublingual formulation of THC and CBD (Sativex ${ }^{\mathrm{TM}}$ ) allows rapid absorptions and avoids hepatic first-pass metabolism, producing plasma levels higher than oral administration but less than inhalation administration [176]. Transcutaneous administration serves as another route to bypass hepatic first-pass metabolism and follows zero-order kinetics, but THC and $\mathrm{CBD}$ absorption decrease due to their hydrophobic structures and resistance from the subcutaneous skin layer $[177,178]$. Studies show that CBD is $10 x$ more permeable in transcutaneous administration when compared to THC, indicating CBD has a more polar structure than THC $[10,77,168,174,177]$.

Once in the bloodstream, $90 \%$ of THC and CBD are distributed to the plasma, while the remaining $10 \%$ are distributed to red blood cells [175]. Both THC and CBD have a distribution volume $\left(V_{\mathrm{d}}\right)$ of $3.4 \mathrm{l} \mathrm{kg}^{-1}$ (calculated following inhaled administration) and $V_{\mathrm{d}}$ of $\sim 32 \mathrm{l} \mathrm{kg}^{-1}$ (calculated following intravenous administration, despite the fact $95-99 \%$ is protein bound to lipoproteins in the plasma). THC and CBD are initially taken up by highly vascularized tissues such as the lungs, heart, brain, liver, mammary gland, fetus, adrenal cortex, and pituitary gland. When administered intravenously, only around $1 \%$ of THC is found in the brain at peak psychoactivity, which could be caused by the high perfusion rate within the brain moving THC in and out. The THC metabolite 11-hydroxy$\Delta$ tetrahydrocannabinol (11-OH-THC) is found in higher quantities in the brain when compared to the unmetabolized THC compound, suggesting the role 11-OH-THC may have in the effects experienced with THC $[77,78,179]$. The increased uptake of $11-\mathrm{OH}-$ THC in the brain may be due to its lower plasma protein binding or the hydroxylated metabolite's ability to pass through the blood brain barrier [76]. With chronic exposure to THC and CBD, eventually the chemicals make their way into adipose tissue, which serves as the long-term storage site.

The liver primarily metabolizes THC via cytochrome P450 (CYP-450) isozymes CYP2C19 and CYP3A4. Some THC can be metabolized outside the liver in tissues that express CYP-450, such as the brain, but the liver serves as the main site of metabolism via its microsomal system [3,168]. Isozymes CYP 450 2C9, 2C19, and 3A4 are involved in the phase-in oxidation of THC, generating hundreds of different metabolites $[10,76,77]$. Specifically, hydroxylation at the $\mathrm{C} 9$ carbon of THC generates 11-OH-THC, the most prominent product following the first round of oxidation. 11-OH-THC serves as an equipotent metabolite and a contributor to psychoactive properties of THC, with blood plasma levels of 11-OHTHC peaking roughly $13 \mathrm{~min}$ after smoking [76]. Subsequent oxidation of 11-OH-THC 
forms the inactivated product THC-COOH which undergoes Phase II metabolism, mainly consisting of glucuronidation into metabolites ready for excretion [76,174]. About $65 \%$ of THC metabolites are excreted within the feces, while the remaining $25 \%$ of metabolites are excreted in the urine $[76,174]$. Overall, the terminal half-life of THC is estimated to be between 25 and $36 \mathrm{~h}$ [179].

CBD is metabolized by CYP2C19, CYP3A4, CYP1A1, CYP1A2, and CYP2D6 [174]. Like THC, CBD C7 carbon is hydroxylated by isoenzymes CYP2C19 and CYP3A4, generating 7$\mathrm{OH}-\mathrm{CBD}$ [76]. The liver further breaks down 7-OH-CBD through glucuronidation, forming metabolites excreted in the feces and urine [76]. However, unlike THC, some CBD is able to be excreted in the feces unchanged [76,174]. As a result, the overall terminal half-life

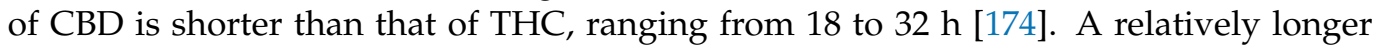
elimination half-life is observed in heavy users of THC and CBD, which is attributed to slow redistribution from deep storage compartments such as within adipose tissues [168].

The metabolism of cannabinoids has several important implications. First, there is extensive interaction with several drug classes on metabolism. Cannabinoid metabolism is usually prolonged in terms of metabolite removal. Since these metabolites are used to test for cannabinoid exposure, such as in a urine toxicology screen, it remains difficult to distinguish acute versus chronic versus accidental exposures [180]. There is a way to assess the level of 9-THC in the blood, but it is laborious and time-consuming.

\section{Tolerance Development}

Chronic administration of cannabinoids over time reduces CB1 receptor density and coupling efficiency, resulting in tolerance to the acute effects of THC such as memory disruption, locomotion impairment, and its analgesic effect [88]. The first stage of desensitization of the CB1 receptors is uncoupling the G-protein receptor to the $\mathrm{G} \alpha \mathrm{i}$-sub-unit, resulting in decreased receptor activation via $\beta$-arrestin involvement [121,181-183]. In rat studies, chronic administration of THC resulted in significant desensitization of CB1 receptors in different brain regions. While every brain region showed some desensitization to chronic administration of THC, different areas within the brain showed higher levels of desensitization as well as time required for desensitization [181,182]. The area of the brain showing the highest degree of desensitization (75\%) and the fastest rate of desensitization (3 days) was the hippocampus [181]. Regions of the brain showing slower rates of desensitization were the cerebellum (7 days) and the globus pallidus (14 days) [181,184]. With different brain regions having variations in rate and degree of desensitization, tolerance to the behavioral effects of THC is developed over different periods. The idea of tolerance toward cannabinoid use can be viewed as beneficial because tolerance can serve as a protective response toward unwanted cannabinoid effects [88].

\section{Endogenous Cannabinoid System}

The identification of $\mathrm{CB} 1$ and $\mathrm{CB} 2$ receptors later led to the discovery of the endocannabinoids anandamide (AEA) and 2-arachidonoylglycerol (2-AG). Both AEA and 2-AG can be synthesized on demand from arachidonic acid within cellular membranes [185]. AEA and 2-AG function as endogenous ligands for the $\mathrm{CB} 1$ and $\mathrm{CB} 2$ receptors, producing effects similar to exogenous THC. 2-AG has full agonist activity toward CB1 and CB2 receptors with low to moderate affinity, while AEA has partial agonist activity toward CB1 but not CB2 receptors with high affinity [154]. Since AEA and 2-AG both consist of uncharged hydrophobic structures, they are unable to diffuse freely after they are released into the intracellular space. There are three possible ways AEA and 2-AG can diffuse into cells. One way is through transport proteins that can bind and translocate the endocannabinoids from one side of the cell. Another way is that the endocannabinoids can be taken up via simple diffusion driven by a concentration gradient established by intracellular enzymatic degradation. Lastly, the endocannabinoids can undergo endocytosis involving caveolae/lipid rafts [154]. AEA is degraded into free arachidonic acid and ethanolamine 
via the enzyme fatty acid amide hydrolase, while 2-AG is degraded into arachidonic acid and glycerol via the enzyme monoacylglycerol lipase [185].

The overall role of the cannabinoid system is somewhat complex. The endogenous cannabinoid system helps maintain normal body CNS functions such as memory, emotional processing, sleep, temperature homeostasis, pain, inflammation, hunger, and immunological responses while also contributing to pathological states such as anxiety, depression, schizophrenia, multiple sclerosis, neurodegeneration, and addiction [154]. The endogenous cannabinoid system also helps maintain PNS and peripheral tissue functions involving pain, energy, metabolism, and cardiovascular and reproductive functions while also contributing to pathological states of glaucoma, cancer, liver, and musculoskeletal disorders [154].

\section{Physiological Effect of Cannabinoids}

\subsection{Cardiovascular Effects in the Context of Cannabinoid Use}

Cannabinoids have several direct and indirect effects on cardiovascular system performance. The indirect effects are mediated by exposure to smoke and carboxyhemoglobin accumulation. Direct effects are primarily via direct CB receptors interaction and secondarily via sympathetic system activation.

Cannabinoids generally have vasodilatory reflex properties if they act through the CB1 receptor [186,187]. The response is complex and may consist of three phases with vagal-mediated hypotension (Phase I), followed by a compensatory increase in blood pressure (Phase II) to culminate in the prolonged hypotensive effect (Phase III) [188]. This latter effect is endothelially mediated and relies on nitrous oxide (NO), as vascular muscles respond with vasoconstriction to cannabinoids through unopposed CB2 interaction $[109,186,189,190]$. TRPV-1 is associated with the reflex bradycardia seen in Phase I, which has a cross function with CB1 receptors in Phase III to produce a hypotensive effect. PPAR and 5- $\mathrm{HT}_{1 \mathrm{a}}$ were also demonstrated as potential mediators for vasodilation [142,188,191-193]. The mechanism has likely central components [188]. What complicates studying this phenomenon is that anandamide results in triphasic effects, but other cannabinoids may not share all components. Being obese and using acetaminophen interfered with the vasorelaxant action of cannabinoids [186]. On the other hand, diabetes enhanced the expression and phosphorylation of CB1 receptors in the aorta with unclear clinical significance [194]. Hypertension resulted in varying degrees of cannabinoid impairments on vasorelaxation in the animal model $[195,196]$. The relaxation lasted for a minimum of $90 \mathrm{~min}$, even in the secondhand intake [197]. Cannabinoids induce tachycardia by increasing the heart rate by approximately 20 to $60 \%$ as compared to baseline. The tachycardic response was linear to the dose, as dosages of $0.022 \mathrm{mg} / \mathrm{kg}$ THC and $0.044 \mathrm{mg} / \mathrm{kg}$ THC resulted in $36 \%$ and $69 \%$ elevation of heart rate from baseline, respectively. In a few cases, tachycardia was accompanied by orthostatic hypotension secondary to a decrease in the predominantly systolic component of blood pressure, but it was not a universal observation for all compounds [198,199]. These hypotensive effects occurred only at higher doses of cannabinoid antagonists [198]. The effect of illicit sympathomimetic additives such as cocaine has to be considered in patients with tachycardia after cannabinoid intake [200]. There is some habituation of tachycardia over weeks of using marijuana, but it was not statistically significant [201]. Ventricular performance was not affected by acute and prolonged cannabinoids in dogs even after 35 days of intake [202]. However, there are reports of cannabinoids causing cardiomyopathy [203].

Concomitantly, smoking one marijuana cigarette increases heart rate by $54 \%$ and reduces the time to the emergence of angina by $50 \%[129,171]$. In another study, cardiovascular risk increased two-fold in young individuals consuming cannabinoids if their consumption was more than four times per month [204]. A similar excessive risk was seen in the case of a cardiovascular accident [205]. However, this is not a uniform finding [206]. It seems well established that an increased risk of a cardiovascular event in the wake of cannabinoid use is present even after singular exposure [207-210]. The increase in tachycardia, which may be a culprit in excessive risk of cardiac events, maybe potentially abolished 
by pretreatment with clonidine or propranolol, both central sympathomimetics [211,212]. However, since cannabinoids may induce tachycardia, resulting in oxygen delivery vs. supply mismatch, the coronary blood supply may be triggered by hypercoagulable states secondary to platelet activation. Furthermore, carboxyhemoglobinemia may be another contributing factor $[82,170]$. Finally, some suggested that the cardiotoxic effect of marijuana may be independent of classical culprits of the acute coronary syndrome [206].

\subsection{Respiratory Effects in the Context of Cannabinoid Use}

Cannabinoids may have a bronchodilator effect via interaction through the CB1 receptor. This interaction is strong enough for some to call for a new drug class designed for b-mimetic resistant individuals [122]. It is also possible that the anti-inflammatory effects of the CB2-mediate effect can facilitate the resolution of acute attacks [213].

THC was shown to significantly improve respiratory function in a study involving asthmatic human patients and healthy individuals [214-216]. The bronchodilator effect lasted for $60 \mathrm{~min}$ in healthy subjects if the cannabinoids were taken orally $[215,216]$. Furthermore, in the study involving asthma patients, $200 \mu \mathrm{g}$ of THC was administered by aerosol to volunteer asthmatic patients at a stable state. Forced expiratory volume in one second (FEV) was recorded in 15-min intervals over the course of an hour after treatment. FEV at 15 min was approximately $0.2 \mathrm{~L}$ and FEV at $60 \mathrm{~min}$ was approximately $0.4 \mathrm{~L}$ [214]. This result shows a significant increase in $p<0.01$ for THC. This study shows that a concentration of $200 \mu \mathrm{g}$ of $9-\mathrm{THC}$ in a $63-\mu \mathrm{g}$ aerosol dose can be safely administered to asthmatic patients to improve respiratory function [214]. However, the benefits of this study proved to be very difficult to replicate, even though small studies confirmed the bronchodilator effect of cannabinoids in very small samples $[98,217]$. No tolerance to this effect over 20 days was observed [218]. Only 9-THC or 8-THC were pharmacologically active, while CBD and CBN were not [218]. These promising results are juxtaposed with the results produced by other clinical trials on the effect cannabinoids have on resolving bronchoconstriction. In COPD individuals, cannabinoids did not improve exercise tolerance, as demonstrated by a welldesigned clinical trial [219]. Others demonstrated the irritable effect of 9-THC, outweighing an increase in large airway obstruction and the direct bronchodilator effect [219]. In another well-conducted study, males below 40 years old demonstrated significant decreases in expiratory flow rates at low lung volumes as well as the ratios of forced expiratory volume in one second to vital capacity; these decreases were to a larger degree than cigarette smokers [220]. In a Norwegian study, users of marijuana reported more use of bronchodilators if they had pre-existing lung conditions [70]. In addition, irritation, mucus production, and local inflammation are seen in cannabinoid smokers compared to healthy individuals and even tobacco users [221]. Hashish users seem to suffer from increased incidence of asthma and bronchoirritation. Consequently, smoking or vaping cannabinoid plants may lead to lung injury similar to that of smoking tobacco $[173,222]$. Marijuana smoking resulted in significantly higher carboxyhemoglobin and tar levels than regular smoking [82,170]. Exposure to cannabinoid smoke resulted in infiltration of neutrophils in the lung tissue [223]. In a longitudinal study of over 2000 young cannabinoid users, the risk of filling prescriptions was 1.72 times higher if an individual was a cannabinoid user [70]. Authors speculated this effect to be secondary to smoke-related irritation and inflammation. It is also likely that pyrolysis of cannabinoids produces bronchoconstrictor or carcinogenic substances. No conclusive data have demonstrated that cannabinoid smoking has the same health effects as tobacco cigarette smoking does, including COPD and cancer [224]. Vaping poses unique risks, as contaminants and additives to the vape medium may cause significant lung damage apart from cannabinoids [62,225]. These changes emerged even though cannabinoids are immune-inhibitory.

Respiratory drive was not affected by regular use of marijuana, but this was not uniform across different studies [128,201,226]. For example, in another study, is the consumption of two $900-\mathrm{mg}$ cigarettes containing $2.2 \%$ marijuana resulted in a change of 
respiratory drive from baseline lasting 8 to 9 weeks [201]. These results are juxtaposed with the suggestion of the beneficial effect of cannabinoids in obstructive sleep apnea [106].

Finally, the case of cannabinoid allergy with compromised airways was described as well [227].

\subsection{Neurological Effects in the Context of Cannabinoid Use}

Cannabinoids have an ambivalent effect on cerebral blood flow. Under normal conditions, the CB1 receptor causes vasodilation with a subsequent increase in cerebral blood flow $[228,229]$. However, during hypoxia or hypercapnia, this effect changes to vasoconstricting. This effect may be responsible for the increased incidence of ischemic stroke among cannabinoid users [205,230]. In particular, young users have a 4.7-times-increased risk of stroke as compared to tobacco smokers [205]. Nevertheless, most of the strokes were survivable with good outcomes [231-233]. This is at least partially attributed to patients young ages. In addition, long-term exposure to cannabinoids results in morphological changes affecting the interpretation of blood flow [234]. This is one of the reasons why there is a complex interaction between the direct vasodilatory actions and the excessive risk of stroke in cannabinoid users [235]. The risk of stroke may increase even after singular exposure, with the risk lasting at least a week [210].

Furthermore, accelerated atherosclerosis and a high rate of intracranial artery stenosis were reported in cannabinoid users and could alternate causation of increased risk of strokes [231]. These data have been juxtaposed with experimental data, suggesting a neuroprotective mechanism of cannabinoid compounds after ischemia [236]. At least part of this neuroprotection is modulated by activation of peripheral MO via CB2 during ischemia [237]. In addition, modulation of neuroinflammation is frequently suggested as the potential beneficial mechanism of the cannabinoid to alter the natural history of neurodegenerative diseases [238-240]. On the other hand, prolonged heavy use of cannabinoids results in hippocampal thinning, neuronal death, and various complications [241-244].

Cannabinoids seem to have a protective effect on neuroinflammation. Downregulation of WNT, an inflammatory pathway, by cannabinoids was linked to improvement in inflammation and a decreased likelihood of Parkinson's disease [13,245]. Subsequently, cannabinoids were studied and suggested as therapeutic for several neurodegenerative and neuroinflammatory symptoms [115]. While the use of cannabinoids appears to be therapeutic for several neurodegenerative and neuroinflammatory symptoms, no definitive evidence to date has been shown promoting their efficacy.

Pupils may be constricted during acute cannabinoid intoxication, but the effect is often compounded by impurities/adulterants of the cannabinoid's preparation [246].

\subsubsection{Pain Perception in the Context of Cannabinoid Use}

The effect of cannabinoids on pain perception is complex, and currently cannabinoids are not officially approved for pain treatment, although their use is permitted in several states per regional regulatory bodies in the USA.

Administration of 8-THC or CBD produced a significant reduction in pain scores in animals in response to capsaicin but only at high concentrations of both compounds: $0.5 \%$ and $1 \%$ for 8 -THC and 5\% for CBD. The mechanism of action for the different cannabinoids was then explored through various antagonists. Administration of the CB1R antagonist, AM251, blocked both the pain-mediating and the neutrophil-migrating effects of 8-THC, suggesting that 8-THC requires interaction with CB1R for its antinociceptive and anti-inflammatory effects. However, the same administration of AM251 did not affect the antinociceptive and anti-inflammatory effects of 5\% CBD. Further research using CB2R - / mice showed that CB2R is not involved in the antinociceptive or anti-inflammatory effects of THC or CBD [247]. Consequently, the CB1 receptor is implicated in direct pain mediation [118]. A noncannabinoid receptor, 5- $\mathrm{HT}_{1 \mathrm{~A}}$, was shown to interact with cannabinoids and produce anti-inflammatory and antinociceptive effects. This interaction was confirmed by using a 5- $\mathrm{HT}_{1 \mathrm{~A}}$ receptor antagonist, WAY100635, which blocked both the 
anti-inflammatory and antinociceptive effects. Additionally, modulation of the TPRV receptor by cannabinoids seems to be implicated in some pain modulation $[120,134,135,137,141]$. Finally, the anti-inflammatory effects of cannabinoid compounds also contribute to pain modulation [248-250].

Similar ambiguity is seen in human studies. The consensus is that cannabinoid compounds have direct and indirect nociceptive activity $[64,79,248,250]$. This pain modulation is particularly effective in chronic pain syndromes associated with neuropathic pain and inflammation [113,163,249-252]. The distinctive mechanism of action from opioids, nonsteroidal inflammatory medication, or acetaminophen makes cannabinoids an attractive adjunct even though the safety profile is not well established [79,112,253]. Finally, cannabinoids seem to reverse morphine tolerance in some cases [254]. Subsequently, nabilone was introduced to the market to treat pain as an adjunct medication $[96,97,99,100]$. However, these data need to be juxtaposed with the recreational use of cannabinoids. Marijuana had hyperalgesic activity and probably enhanced the perception of pain. In contrast, heavy smoking had little effect on discriminability and caused an increase in the pain report criterion (190). These effects persisted up to 4 weeks. Heavy consumption was $2 \%$ THC in $20 \mathrm{mg}$ per 3-12 cigarettes per day (190). Differences in hosts' expression of CB1 and CB2 receptors may be at fault in conjunction with the composition of marijuana smoke compounds.

The data demonstrated the efficiency of the cannabinoids in low back pain, headache, cancer, and surgical pain $[112,250,255]$. Cannabinoids may be a viable strategy to limit opioids since their effects are independent and addictive, considering their independent mechanism of action and less-addictive potential [251,256,257].

\subsubsection{Seizure Threshold in the Context of Cannabinoid Use}

A decreased expression of CB2 receptors results in a lower seizure threshold [258-260]. Animal models and humans showed a beneficial effect of cannabinoids, particularly CBD, on seizure treatment. For example, 0.01 to $100 \mu \mathrm{M}$ of CBD suppressed epileptiform activity in slices of the hippocampus region, as determined by the frequency of epileptiform local field potential (LFP) burst amplitude as well as burst duration [261]. One study applied this finding in human trials of patients with Lennox-Gastaut syndrome and Dravet syndrome, which are characterized by frequent seizures. Patients were tested with $20 \mathrm{mg} / \mathrm{kg}$ daily of cannabidiol. Of the 121 patients administered treatment, 43.9\% reported a reduction of monthly drop seizure frequency. The cannabidiol was administered as an add-on therapy for treatment-resistant patients. Most studies testing the efficacy of cannabidiol as an anticonvulsive showed that less than $50 \%$ of patients proved to have reduced frequency of seizures, although most patients still experienced an adverse event. In this study, approximately $44 \%$ of the cannabidiol group experienced reduced seizures, whereas $86 \%$ of the same test group experienced adverse effects such as diarrhea, somnolence, pyrexia, decreased appetite, and vomiting. Furthermore, the extensive and complex metabolism of cannabinoids remains a problem with several interactions with other medications and significant effects of first-pass metabolism [90,174,262].

The benefits of cannabinoids have also been tested in seizure-like disorders. Initial studies focused on treating resistant seizures in the child population [263]. However, increasing data suggest that cannabinoids could be useful as treatment adjuncts [264-267]. The proposed mechanism of action is through CB2 receptors, resulting in hyperpolarization of surrounding membranes and the diminished effect of glycine toxicity [147,148,259,268]. Despite the enthusiasm and unwavering interest in using cannabinoids in epileptic treatment, the trials are limited to children and seizures resulting from neurodevelopmental, inherited and inflammatory disorders of the brain that are refractory to other treatments [266,268-271]. This somewhat cautionary approach may balance the hope that cannabinoids may provide multimodal mechanisms addressing several mechanisms underlying seizures (anti-inflammatory or metabolic) and the overall concern of side effects from these compounds [272]. 


\subsection{Psychological, Behavioral, and Psychiatric Effects of Marijuana}

There is significant euphoria/positive reinforcement during the intake of psychoactive cannabinoids combined with an anxiolytic effect $[3,119,153,273,274]$. The mechanisms involved with the activation of CB1 receptors by ligands (most commonly 9-THC) result in the reward's reinforcement $[119,275]$. Activation of CB2 receptors seems to have the opposite effect [275]. Consequently, the effect of the cannabinoid compound will depend on the composition of its preparation (potency, enantiomer composition, and pharmacokinetics). Several regions of the brain are stimulated, particularly the mesolimbic dopaminergic system, followed by other parts of the brain, such as the posterior ventral tegmental area, the shell of the nucleus accumbens, and many others [273,274].

Cannabinoids influence the ability to make decisions in several settings. A synergistic relationship with alcohol showed impaired driving and nondriving skills [276]. Interestingly, willingness to be engaged in impaired activities was not changed [276]. This may suggest that cognitive impairment is very insidious.

What is of particular concern is the increased risk of psychiatric disorders. A longitudinal study of Swedish conscripts with more than 50 incidents of cannabinoid use resulted in a six-times-increased risk of emergence of schizophrenia in an independent way from other psychiatric disorders [277]. These psychiatric findings are similar to a previous study conducted in 1969 and other following studies. However, the emergence of psychologic changes may be time-delayed, as acute doses of cannabidiol ranging from 10 to $600 \mathrm{mg}$ and chronic administration of $10 \mathrm{mg}$ for 20 days or $3 \mathrm{mg} / \mathrm{kg} /$ day for 30 days did not induce psychologic or physical symptoms suggestive of psychotropic or toxic effects [278]. Cannabis influence on mood is very complex, further clouded by impurities of the cannabinoid's preparations. Often the opposite effect is reported, including calming violent behavior induction [279]. However, this interaction is further complicated by prolonging several illicit substances and alcohol metabolism when taken with THC by interaction with microsomal hepatic system [280].

\section{Overdose, Addictive Potential, and Withdrawal}

Acute intoxication associated with cannabinoids is relatively uncommon but is of increasing frequency due to the introduction of synthetic cannabinoids into current preparations as well as the increase in 9-THC concentrations over time [281]. The effects are often compounded by adulterants added to the street preparation of cannabinoids. The effect of acute intoxication and the related "high" can be antagonized by physostigmine, as demonstrated in a few individuals [282]. Anxiety, hostility, paranoia, flushed eyes, erratic behavior, and tachycardia are commonly found [78]. However, these effects are unlikely to occur in cases of cannabidiol consumption $[78,281]$.

THC has psychoactive components that contribute to its addictive potential $[119,283]$. 9-THC activates the mesolimbic system when ingested, causing an increase in free dopamine, which drives reinforcing and rewarding effects of the drug [119]. When rats were introduced to self-administration of THC directly into the posterior ventral tegmental area or the nucleus accumbent, the rats learned to lever-press to increase injections into the areas [274]. When THC was replaced with SR141716A, a CB1 receptor antagonist, the lever pressing responses were stopped [274]. This experiment shows the reinforcing properties of THC as well as the role the CB1 receptor plays in establishing such behaviors. With chronic administration of THC over time, tolerance develops by decreased densities of available CB1 receptors.

Dependence is defined as undesirable physical symptoms if a substance is suddenly stopped or taken in smaller quantities [283]. Common symptoms of THC withdrawal include anger, anxiety, decreased appetite, weight loss, irritability, restlessness, hostility, and sleep disturbance [283-285]. These symptoms usually occur $24 \mathrm{~h}$ after the last use, peak in 1-7 days, and last about $2-3$ weeks [286,287]. It is estimated that $47 \%$ of regular users will experience withdrawal during their life [288]. Experiencing withdrawal symptoms is not considered life-threatening. Nabilone can be used in case-by-case cases to alleviate 
withdrawal symptoms, although this is an off-label use. In addition, dexmedetomidine was successfully used in one case report, suggesting that some of the symptoms of cannabinoid withdrawal may be secondary to cannabinoid interaction with the $\alpha 2$ receptor [289]. However, dexmedetomidine is used with several other withdrawal symptoms to lessen the severity of symptoms.

\subsection{Coagulation and Cannabinoids}

Endocannabinoids, specifically 2-AG, interact with other proinflammatory markers to influence hemostasis via cannabinoid and noncannabinoid pathways [290-292]. Plateletactivating factor (PAF), a potent mediator of inflammation, is released from activated neutrophils, macrophages, platelets, and endothelial cells. As local levels of PAF increase, studies show that macrophages, platelets, and endothelial cells release significant levels of endocannabinoid 2-AG but not anandamide [293]. When local levels of 2-AG increase, 2$A G$ is shown to interact with platelets through receptors outside of the common CB1/CB2 receptors. In the presence of a 2-AG CB-receptor agonist or antagonist, both fail to induce or prevent platelet aggregation, respectively, which was confirmed by the lack of CB1 or CB2 receptor mRNA in human platelets [126]. 2-AG promotes platelet shape change, granulation secretion, and increases in cytosolic $\mathrm{Ca}^{2+}$ and TxA2 formation, ultimately resulting in platelet aggregation [126]. Synthetic cannabinoids such as CBD do not have the same platelet activation and aggregation effect compared to the endocannabinoid anandamide [294]. Although anandamide can cause platelet activation, it does not activate platelets to the same magnitude as 2-AG. In the presence of PAF, anandamide is not generated by macrophages or platelets, thus supporting 2-AG being the primary endocannabinoid for hemostasis [293].

\subsection{Liver Effects in the Context of Cannabinoid Use}

Cannabinoids interact with the liver in several different ways. The role of liver metabolism of cannabinoids has been described above.

Several interactions with anesthetics are possible (Table 3). Cannabinoids will compete for CYP3A4 and CYP2C9 enzymes, resulting in a possible decrease in the metabolism of other medications utilizing the same enzymes. Diminished metabolism of ethanol and barbiturates was reported [295-297]. Polymorphisms in CYP2D6 may be of particular importance for competing for metabolism since cannabidiol significantly impairs this pathway [295]. Cytochrome P25C9 or 3A may have inhibitory influences on processing the cannabinoids and other anesthetics [296,297]. Secondly, cannabinoids significantly influence the immune system; thus, their presence may modulate several autoimmune and toxic processes by modulating the NF- $\mathrm{kB}$ pathway. Thirdly, paracetamol and cannabinoids have several intense interactions with difficult-to-judge clinical importance. Finally, there are suggestions of cannabinoids contributing to nonalcoholic liver disease, fibrosis, and inflammation, but the data are conflicting and inconclusive [298,299].

\subsection{Immunology Performance in the Context of Cannabinoid Use}

Cannabinoids have both direct and indirect effects on the immune system. The direct effects are mediated via CB2 cannabinoid receptors. The indirect effects are mediated by cannabinoids interacting with peripheral organs affecting immunological performance with CB1 and CB2 receptors variably involved. Other receptors may be involved as well [319]. Neuroimmunological connections are probably the most important in modulating immunologic responses, yet these connections are extremely difficult and complex.

Serum profiles of male cannabinoid users demonstrated a profound effect on IL-12related activation patterns as well as the activation of MAPK kinases and NF- $\mathrm{B}$ pathways [320]. These effects were complex, with diverse outcomes occurring on activation and inhibitory markers represented by 55 proteins being upregulated and 66 being downregulated. Of significance, liver $X /$ retinoid $X$ receptor (RXR) activation and acute phase response signaling were most affected when monitoring in vitro experiments [320,321]. In 
addition, activation of inflammasome 3 was significantly reduced by CBN [322]. This immunomodulatory profile suggests that cannabinoids may have a predominantly inhibitory effect on the immune system, which is reinforced by the reduction in IL-1 $\beta$ production [323].

Table 3. Interaction between cytochromes and anesthetic agents while being modulated by cannabinoids.

\begin{tabular}{|c|c|c|c|}
\hline Cytochrome & Cannabinoid & Cannabinoid Effect & Anesthetic \\
\hline CYP2B6 & THC, CBD & $\begin{array}{l}\text { THC and CBD both } \\
\text { are inhibitors [300] }\end{array}$ & Propofol [301], Ketamine [302,303] \\
\hline CYP2C9 & $\begin{array}{l}\text { THC, Cannabinol } \\
\text { [304] }\end{array}$ & $\begin{array}{l}\text { THC as inhibitor } \\
{[300,305]}\end{array}$ & $\begin{array}{l}\text { Propofol [301], Ketamine [302,303], } \\
\text { Rocuronium [306] }\end{array}$ \\
\hline CYP2E1 & $\begin{array}{l}\text { THC metabolites, } \\
\text { CBD }\end{array}$ & $\begin{array}{l}\text { Competetive } \\
\text { inhibition [300] }\end{array}$ & $\begin{array}{l}\text { Halothane [307], Isoflurane [307], } \\
\text { Sevoflurane [307], Enflurane [307], } \\
\text { Desflurane [307,308] }\end{array}$ \\
\hline CYP3A4 & $\begin{array}{l}\text { THC, CBD, } \\
\text { Cannabinol }\end{array}$ & $\begin{array}{l}\text { CBD is an inhibitor } \\
{[300,309]}\end{array}$ & $\begin{array}{l}\text { Ketamine [302], } \\
\text { Midazolam [310], } \\
\text { Diazepam [311], } \\
\text { Fentanyl [312], } \\
\text { Rocuronium [306], } \\
\text { Codeine [307,313], } \\
\text { Propofol [301], } \\
\text { Acetaminophen [314] }\end{array}$ \\
\hline CYP2A6 & $\mathrm{THC}$ & $\begin{array}{l}\text { Genotype-dependent } \\
\text { [295] }\end{array}$ & Dexmedetomidine [315] \\
\hline CYP2C19 & THC, CBD & $\begin{array}{l}\text { THC and CBD are } \\
\text { both inhibitors [309] }\end{array}$ & $\begin{array}{l}\text { Diazepam [311], } \\
\text { Rocuronium [306] }\end{array}$ \\
\hline CYP1A1/2 & CBD & $\begin{array}{l}\text { CBD is an inducer } \\
\text { [309] }\end{array}$ & Diazepam [311] \\
\hline CYP2D6 & THC, CBD & $\begin{array}{l}\text { THC and CBD are } \\
\text { both inhibitors [300] }\end{array}$ & $\begin{array}{l}\text { Tramadol [316], } \\
\text { Codeine }[314,317], \\
\text { Oxycodone }[314,318], \\
\text { Hydrocodone }[303,318] \text {, } \\
\text { Methadone }[303,318]\end{array}$ \\
\hline
\end{tabular}

Both CBD and THC affect lymphocyte proliferation, with CB1 and CB2 receptors playing important roles in immunomodulation [125,324]. THC primarily utilizes CB1 receptors, but it has been shown that $\mathrm{CB} 2$ receptors have the greatest effect in decreasing lymphocyte proliferation. Cannabinoid-induced lymphopenia causes the greatest decrease in T-cells, T-helper cells, cytotoxic T-cells, and B-cells in the lymphocyte subset. The ratio of Th1 to Th2 cells may be affected [325]. However, the total numbers of NK and NKT cells were independent to that of lymphocytes [326]. This concludes that cannabinoid-induced lymphopenia is somewhat a selective matter. CBD mostly inhibits T-cell invasion to an injury site. T-cell differentiation and invasion are closely linked to cytokine and chemokine levels. These cytokine levels are proinflammatory following an injury. When rats subjected to a spinal cord injury were given $\mathrm{CBD}$, there was shown to be a decrease in cytokine levels and T-cell invasion. A similar suppressive effect is seen in monocytes and their response to bacterial and infection stimuli $[238,324,327,328]$. This immunosuppressive effect also extends to dendritic cells [329]. In a very elegant in vitro experiment, 9-THC was demonstrated to interrupt the interaction between T-cells and astrocytes, suggesting a potential dendritic cell-related immunosuppression [330].

These immune-modulatory properties of marijuana smoke have to be isolated from the effect of the smoke itself $[170,219,223,224,331]$. Cannabinoid compounds can also induce cell death at high concentrations [332].

The relevance of the immunosuppressive effect of cannabinoids is difficult to judge clinically. However, it may be responsible for increased susceptibility to pulmonary infec- 
tion in recreational users and patients taking cannabinoid compounds for clinical conditions $[90-92,325,333]$. At the same time, antinociceptive and neuroprotective mechanisms are dependent on the anti-inflammatory action of cannabinoids [74,123,239,334-336].

\section{Anesthetic Consideration for Cannabinoid Use}

Most cannabinoid users are young. Consequently, their number of comorbidities is low, presenting a little challenge. However, on the other hand, a significant subgroup of individuals with significant cannabinoid intake are secondary to several medical, mostly chronic, severe conditions.

\section{Preoperative Period}

Four main considerations present significant challenges for anesthesiologists during the perioperative period: (1) gauging the intake of cannabinoids, (2) evaluating the effects of cannabinoids, (3) assessing the competency to consent, and (4) management of cannabinoid medications (Figure 2).
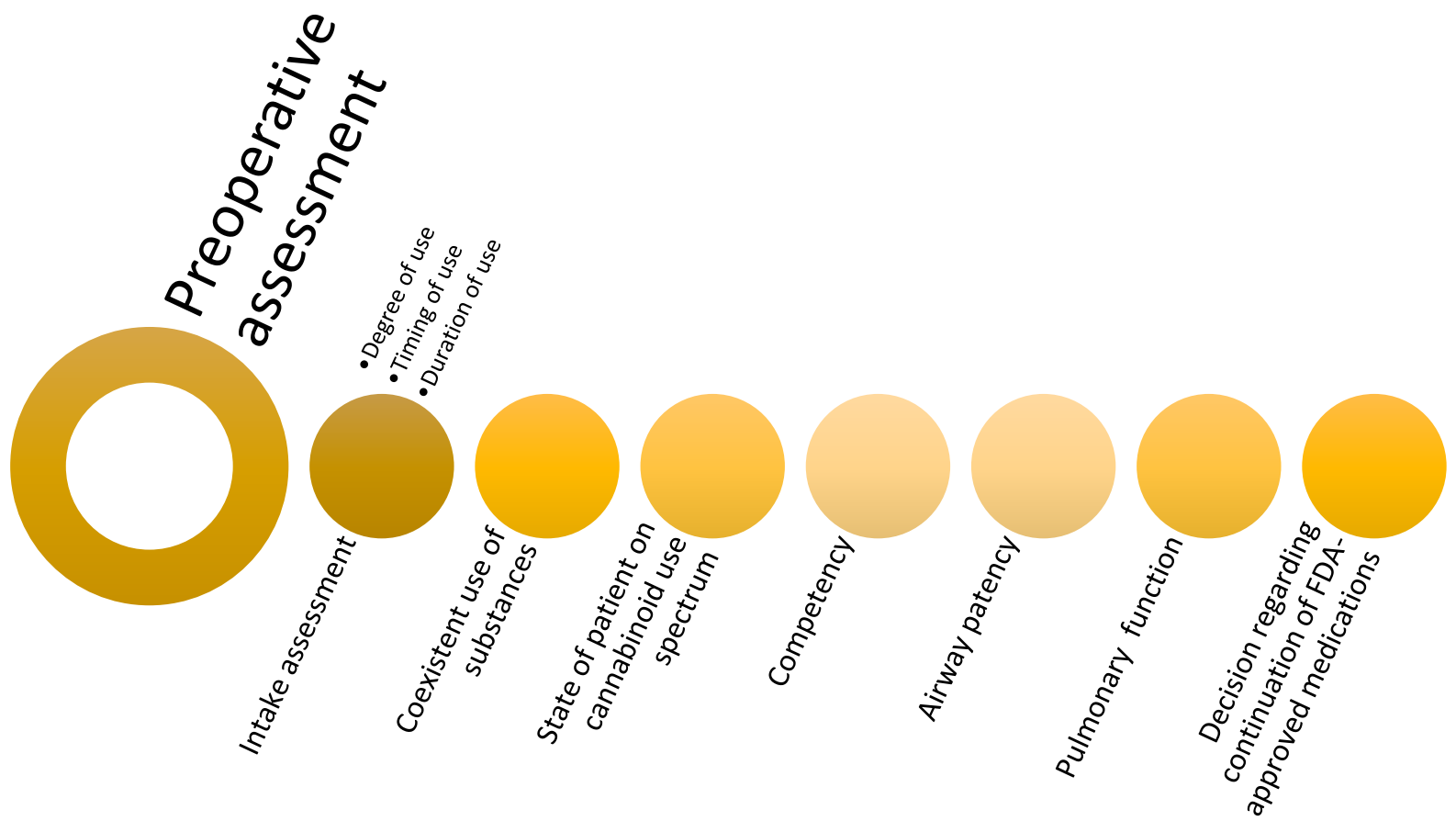

Figure 2. Preoperative consideration in anesthesia in an individual with cannabinoid intake.

A formidable challenge is gauging the intake of cannabinoids, as the dosages and potency of different cannabinoid preparations vary in strength and composition $[18,19,35,37]$. The standardization of the dosages is scant and complicated, with the concentration of 9THC possibly being affected by 8 -THC while being inversely related to CBD $[77,78,83,179]$. Furthermore, synthetic cannabinoids may further affect potency [10,207]. Considering the higher prevalence of other illicit drugs among cannabinoids, one must consider the possibility of multi-drug abuse with obvious implications for anesthesia management $[9,200,276]$. Cannabinoids have several pleiotropic properties $[2,14,87,107,117,156,167,169,176]$. Their intake varies greatly depending on the route of consumption, the consumers' habits, the reason for consumption, and the corresponding effects on the cardiac, immunological, and nervous systems $[17,26,44,46,71,72,256]$. The lack of standardized tools available to providers to assess cannabinoid use compounds the problem. The high variability in cannabinoid preparation and biological actions effectively limits accurately gauging the risk related to cannabinoid intake during anesthesia management. With some of the effects of cannabinoids being nonlinear, it only adds to the difficulty with anesthesia management. 
An individual may present in five potential states related to cannabinoid use: acute intoxication, chronic/habitual intake, withdrawal from cannabinoids substances, positive urine toxicology screen, or taking FDA-approved medication. The sign of acute intoxication includes symptoms of conjunctivitis, bloodshot eyes, dry mouth, tachycardia, and hypotension [337-339]. The demeanor is euphoric along with impairments to motor skills and short-term memory [67]. The patient may also present with excessive anxiety and paranoid ideation $[67,337,338]$. These symptoms may be difficult to recognize in individuals with second-hand exposure to cannabinoid compounds who cannot communicate effectively [337]. There is also a possibility that an intoxicated patient may suffer from a stroke, acutely masquerading intoxication [230]. The sign of chronic intake may be difficult to identify, considering that an individual may be partially habituated to cannabinoids' effects while suffering from consequences of prolonged cannabinoid use. The classical urine test remains positive for days after cannabinoid intake, even if this was second-hand smoke or bystander intake. Only simultaneous blood draws to urine collection allow for assessing acute vs. chronic/historic exposure, as THC can last in the blood for 2 to $6 \mathrm{~h}$ [41,340-342]. In some instances, patients may present with signs of acute cannabinoid withdrawal centered around tachycardia and psychological disturbances (anxiety, hostility, etc.) [284,285]. The withdrawal manifests mostly with extreme agitation that may be managed conservatively with benzodiazepines, $\alpha 2$ agonists, and anxiolytics [285,286,289]. Long-term marijuana users can also suffer from hyperemesis syndrome [343]. Finally, the individual may be prescribed a cannabinoid-based medication in which most of them should continue through surgery $[21,49,89,100]$.

When treating a patient suspected of cannabinoid use, it is very important to determine their ability to give consent properly. Cognitive impairment may be prolonged, making it difficult to judge the patient's ability to give consent [276]. In general, intake of cannabinoids is related to impaired judgment but not risk avoidance [276,344]. Chronic exposure to cannabinoids results in morphological changes to the brain with an unclear ability to make decisions [234,345]. This is further complicated by the inability of current testing to recognize acute vs. delayed/chronic cannabinoid intake, as the metabolites measured in urine have a long half-life [180]. Finally, exposure to cannabinoids may occur in an insidious/second-hand way, impacting the ability to consent $[66,68,230,346]$. On the practical level, assessing an individual's ability to render an informed decision should be undertaken and documented in the chart following standard practices.

In terms of cannabinoids affecting the assessment of perioperative fitness for surgery, cannabinoids have a complicated influence, and no studies exist showing if cannabinoid users suffer from an increased burden of ailments and illnesses. Overall, the effect of cannabinoids on the cardiovascular system is hypotension combined with tachycardia. Interestingly, cannabinoid concentrations increase in coronary arteries post-acute coronary syndrome, suggesting a beneficial or compensatory effect. This effect may be balanced against the risk of myocardial ischemia, platelet activation, cardiac arrhythmia, and cardiomyopathy [204,208,209,347]. Of note, increased risk of a coronary event is prolonged and occurs after even a single intake of cannabinoid compounds [204]. Concern regarding the respiratory system should focus on the potential effect of smoke and vape inhalation as an inducer of lung damage or affecting mucus production [62,73,172,173,225]. In addition, the upper airway should be evaluated for potential problems during intubation. In an interesting example, a case study regarding a 17-year-old male who smoked marijuana before his scheduled tympanomastoidectomy showed that his postoperative recovery was complicated by uvular edema, which led to blockage of his glottal opening corresponding to hypoxia [348]. In another case, necrosis of the uvula occurred during anesthesia in a cannabinoid user [349]. Other abnormalities of the oropharyngeal cavity may be present [350,351]. All possible causes for these complications to emerge, such as allergies and trauma, were considered, but eventually, cannabis use was decided to be the most likely cause [352] 
Significant consideration should be devoted to the interaction of drugs with cannabinoids in current users. While some medications may have minimal interactions, cannabinoids interact extensively with protein binding and liver metabolism, affecting the level of other drugs and their metabolism.

\section{Operative Period and Cannabinoids}

The effect of cannabinoid intake on intraoperative anesthesia management is mostly related to potential effect on sympathetic drive and airway management (Figure 3). Acute and chronic consumption of cannabinoids can have different effects on anesthetic requirements. In a human study examining the effects of reported cannabis use and propofol induction, patients reporting cannabis use for over a week required significantly higher doses of propofol to achieve a BIS $<60 \%$ as well as higher doses of propofol to achieve endotracheal tube intubation [353]. The anesthesia induced by ketamine, thiopentone, or propanidid was prolonged if 9-THC was administered in mice [354,355]. This prolongation effect was not seen with the administration of cannabinol. However, pentobarbital was prolonged by cannabidiol [354]. One study suggested prolongation of ether anesthesia [355]. Another study demonstrated a reduction in MAC for sevoflurane, but only if intraperitoneal morphine at $5 \mathrm{mg} / \mathrm{kg}$ was given concomitantly with cannabinoids to animals [356]. In rats, pretreatment with 9-THC reduced MAC sevoflurane by $26 \%$ [357]. However, another study in human subjects found higher BIS values in concurrent cannabinoid use [358]. Furthermore, in a double-blind, randomized control study, consumption of cannabinoids prior to surgery led to an increased average BIS during steady-state anesthesia ${ }^{17}$. Considering all the facts, cannabinoid consumption has increased EEG activity, rendering BIS a less reliable measurement of anesthetic depth while affecting the anesthesia requirements. No studies have explored the effects of cannabinoids on spinal, epidural, and regional anesthesia performance. Conversely, anesthesia may prolong the duration of cannabinoid metabolism, since it interferes with CYP3a metabolism [359].

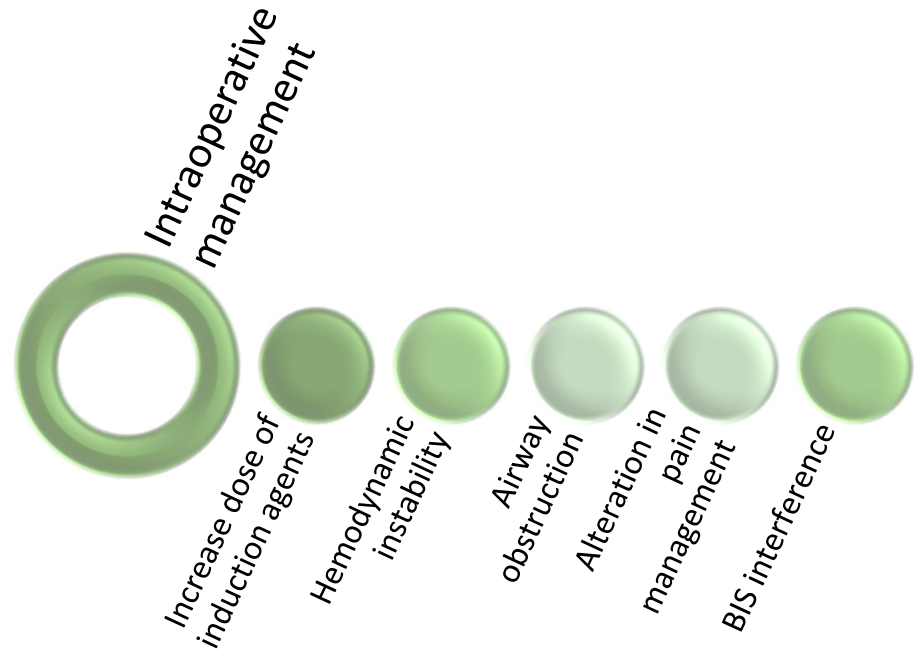

Figure 3. Intraoperative management of the individual with cannabinoid intake.

With the increased prominence of laced marijuana, it is important to consider the effects of additive substances on cannabinoids. A case report of a patient with a history of smoking marijuana laced with amphetamines experienced an incidence of severe hypotension after intubation and administration of sevoflurane [360]. The patient's hypotension was unresponsive to phenylephrine and a bolus of crystalloids. Eventually, the patient's blood pressure was responsive and stabilized with the administration of epinephrine [360]. With increased consumption of cannabinoids worldwide, it is important to consider potential additives, as the patient may not be aware of them. 
Acute cannabinoid use seems to be related to increased blood pressure, tachycardia, and increased or decreased cardiac contractility [128,129,196,198-200,202,206,207,232,361-363]. The limitation of these data is that the perioperative intake of cannabinoids is difficult to standardize even within the same patient. In addition, most of these effects are triggered by the interaction of the cannabinoids with the autonomic nervous system [128,207,363]. Consequently, it is unclear if a paradoxical hemodynamic response is possible in the case of a patient with sympathetic exhaustion while taking cannabinoids [127,129,361,362]. Concomitant intake of $\beta$-blockers may impact the cannabinoid-triggered responses. The type of response from prolonged consumption of cannabinoids is unclear, but some suggest an enhanced parasympathetic response [361]. The question of perioperative arrhythmias may be a more serious consideration, as arrhythmias were reported to be of higher incidence within cannabinoid users [364]. The risk of adverse cardiovascular events has not been evaluated definitively, but acute coronary syndrome and arrhythmias have been reported [208,348,364]. However, the risk of stroke seems to be the primary consideration in case series and metanalysis [232,363]. Acute coronary syndrome is limited to case reports and linked to increased platelet activation and autonomic instability [126,196,207,292]. Interestingly, endogenous cannabinoids are at an increased concentration in hypoperfusion syndrome and serve as coronary dilators [347]. The effect of cannabinoids on the pulmonary system seems to be limited to potential irritation, inflammation, and immune suppression [90-92,170,215,219,224]. Before intubation, a risk assessment should be conducted, focusing on potential swelling of the upper airway tissues and potential increased resistance of the lower airway [73,82,170,216,352]. During management, an increased risk of airway obstruction is present, especially in prolonged users of cannabinoids [170,215,216,219,224]. Should these complications emerge, they should be managed per standard of care (application of bronchodilators, suctioning, and bronchoscopy). No definite data exist linking cannabinoid use to clinically important effects on urinary, endocrine, and hepatic systems. It is unclear if cannabinoids are related to the emergence of malignant hyperthermia, but their intrinsic $\alpha 2$ activity suggests otherwise [94,130]. Thermoregulation seems to be intact, as one study demonstrates an identical incidence of shivering among marijuana users of a variety of levels [365]. The involvement of cannabinoids in lacrimation can place a patient at higher risk of corneal injury [366].

\section{Postoperative Period and Cannabinoids}

Postoperative management of patients who are cannabinoid users should be focused on: management of typical postoperative complications (nausea, vomiting, pain control, shivering, urinary incontinence and retention, and delirium), management of potential withdrawal symptoms, and mitigation of the risks associated with long-term cannabinoid use (Figure 4).

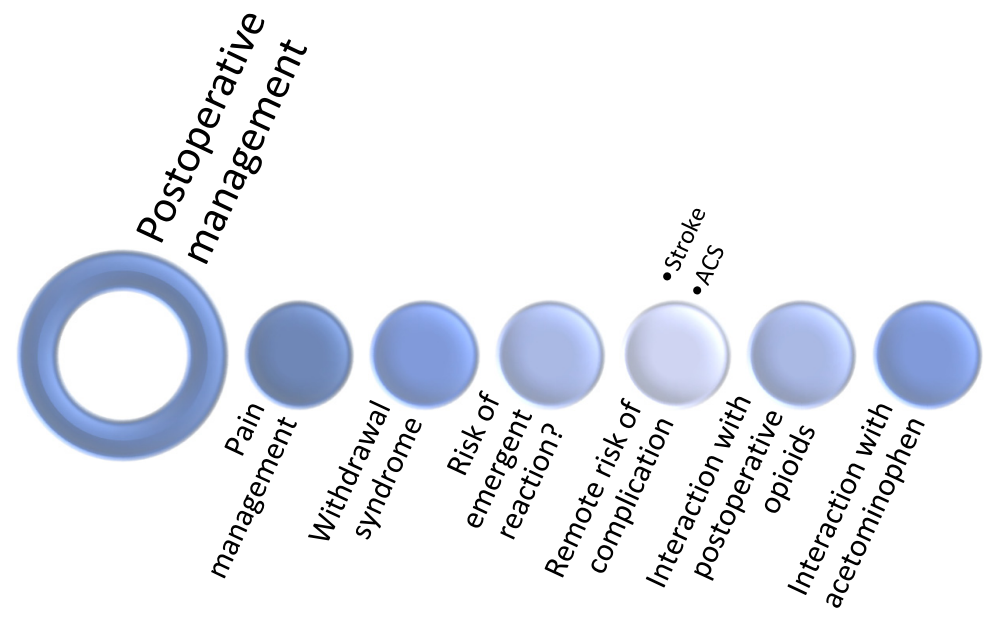

Figure 4. Postoperative consideration for cannabinoid users. 
Despite the high potential of cannabinoids resulting in psychoactive disorders, there are no reports of increased frequency of emergence reaction after surgery, despite the increased risk of dementia, schizophrenia, and cognitive decline [277,345]. The effects of cannabinoids on postoperative pain management are not well established, despite some suggestions of using these compounds for chronic pain. Three studies demonstrated significant heterogeneity in effects [367-369]. These studies demonstrated that analgesic, antianalgesic, and hyperanalgesic effects of cannabinoids were partly related to their doses consumed. Though cannabinoids are not used as first-line treatment in pain management, experimental and clinical data show that concurrent cannabinoid use will have unpredictable effects on postoperative pain management with opioids. What could be of particular interest is the interaction of cannabinoids with opioids on respiratory depression, since there are at least some suggestions that cannabinoids can be utilized to improve obstructive sleep apnea $[106,107,263]$. Few cases are described, as there are potential liver injuries during concurrent cannabis and acetaminophen use [370]. THC and nabilone have both shown to have little to no effect on perioperative nausea and vomiting (PONV), even though the cannabinoids may directly mediate this effect $[55,133,160]$. A study involving THC to alleviate PONV symptoms revolved around the hypothesis that THC would reduce the risk of PONV by $25 \%$ compared to a placebo. Forty patients with high susceptibility to PONV were administered $0.125 \mathrm{mg} / \mathrm{kg}$ of THC or a placebo and were observed for $24 \mathrm{~h}$ after surgery. The primary outcome observed was the incidence of PONV. However, the study was discontinued due to the lack of efficiency of THC against PONV. In a study involving nabilone for PONV treatment, 340 participants were given either nabilone or a placebo, and the results showed that both subject groups experienced approximately a $20 \%$ likelihood of PONV. Both studies show that THC and nabilone have little effect on the symptoms of PONV when compared to a placebo. These are interesting findings, as some advocate utilizing cannabinoids to treat nausea in the wake of chemotherapy $[48,55,97,160]$. Location of the CB1 receptor on the prostate, vas deferens, and bladder suggest a potential role of cannabinoids in urinary retention, but clinical data are lacking except for a one-time remote report [371].

The emergence of postoperative complications in cannabinoid users is continuing to be established. In general, one study demonstrated a lack of major perioperative events in cannabinoid users. A total of 1818 patients consisting of cannabis users (606) and controls (1212) were analyzed and assessed in terms of perioperative complications [372]. No difference was found statistically significant between the two groups [372]. This study was completed through a retrospective electronic medical record review [372]. However, in a much larger study of over 27,000 records, the active cannabinoid user had increased odds of experiencing a myocardial infarction [373]. This finding is aligned with a prior observation of increased risk of cardiac events in cannabinoid users in general [129,196,206,232,361,362].

Finally, the potential for cannabinoid withdrawal should be assessed in conjunction with other potential withdrawal syndromes in polysubstance users. Cannabinoid withdrawal is usually unpleasant but rarely results in difficult complications.

\section{Limitations}

The above overview is a very basic guide due to the paucity of recent data and the complex nature of cannabinoids' biological properties. The FDA's classification of marijuana as an illicit substance resulted in a paucity of research. Consequently, several studies cited are 40 years old or older. Several studies are in vitro or in animals. Their translation in the effect of anesthesia performance during surgery may be limited. Most current evidence is related to case reports or case series with obvious limitations. The effect of the anesthetic cannot be discerned from other illicit substances because of a lack of a reliable way to distinguish the dose, composition, and timing of cannabis compounds. Of note, cannabinoid users, most of the time, are not privy to this information, forcing anesthesiologists to work in the dark. 


\section{Conclusions}

Cannabinoids are biologically active compounds with highly unstandardized and complex chemistry. Lack of standardized tools and modern knowledge affects the ability of anesthesiologists to predict the effects of cannabinoids on anesthesiology execution accurately. The effects may be substantial but nonlinear, adding another layer of complexity. Though cannabinoid intake should be considered, anesthesia plans should be executed carefully and take into account the potential effects of cannabinoids. The FDA-approved cannabinoid compounds should be continued during treatment.

Author Contributions: K.L.-Conceptualization; validation investigation; data curation; manuscript writing; figure and table creation; review and editing; J.W.- -validation investigation; data curation; manuscript writing; figure and table creation; review and editing. All authors have read and agreed to the published version of the manuscript.

Funding: This research did not receive any specific grant from funding agencies in the public, commercial, or not-for-profit sectors.

Institutional Review Board Statement: Not applicable.

Data Availability Statement: The datasets used and/or analyzed during the current study are available from the corresponding authors on reasonable request.

Acknowledgments: Authors would like to thank Danyal Ghani and Emily Griggs for able help in writing this manuscript.

Conflicts of Interest: The authors declare that they have no competing interests.

$\begin{array}{ll}\text { Abbreviations } \\ \text { 2-AG } & \text { 2-arachidonoylglycerol } \\ \text { 5-HT1A } & \text { 5-hydroxytryptamine } \\ \text { 8-THC } & (-) \text {-trans- } \Delta \text {-tetrahydrocannabinol } \\ \text { 9-THC } & (-) \text {-trans- } \Delta \text {-tetrahydrocannabinol } \\ \text { AEA } & \text { arachidonoylethanolamide } \\ \text { cAMP } & \text { cyclic adenosine monophosphate } \\ \text { CB1 } & \text { Cannabinoid receptor 1 } \\ \text { CB2 } & \text { Cannabinoid receptor } 2 \\ \text { CBC } & \text { Cannabichromene } \\ \text { CBD } & \text { Cannabidiol } \\ \text { CBN } & \text { Cannabinol } \\ \text { CYP-450 } & \text { cytochrome P450 } \\ \text { DOR } & \delta \text {-opioid receptor } \\ \text { GDP } & \text { guanosine diphosphate } \\ \text { GTP } & \text { guanosine triphosphate } \\ \text { MOR } & \mu \text {-opioid receptor } \\ \text { NK } & \text { natural killer } \\ \text { THC } & \text { tetrahydrocannabinol } \\ \text { NADA } & \text { N-arachidonoyl-dopamine } \\ \text { ODA } & \text { N-oleoyl-dopamine } \\ \text { GLYR } & \text { Glycine Receptor } \\ & \end{array}$

\section{References}

1. Gaoni, Y.; Mechoulam, R. Isolation, structure, and partial synthesis of an active constituent of hashish. J. Am. Chem. Soc. 1964, 86, 1646-1647. [CrossRef]

2. Pollastro, F.; Minassi, A.; Fresu, L.G. Cannabis Phenolics and their Bioactivities. Curr. Med. Chem. 2018, 25, 1160-1185. [CrossRef] [PubMed]

3. Radwan, M.M.; Elsohly, M.A.; Slade, D.; Ahmed, S.A.; Khan, I.A.; Ross, S.A. Biologically active cannabinoids from high-potency Cannabis sativa. J. Nat. Prod. 2009, 72, 906-911. [CrossRef]

4. Radwan, M.M.; Chandra, S.; Gul, S.; ElSohly, M.A. Cannabinoids, Phenolics, Terpenes and Alkaloids of Cannabis. Molecules 2021, 26, 2774. [CrossRef] [PubMed] 
5. Lowe, H.; Toyang, N.; Steele, B.; Bryant, J.; Ngwa, W. The Endocannabinoid System: A Potential Target for the Treatment of Various Diseases. Int. J. Mol. Sci. 2021, 22, 9472. [CrossRef]

6. Turner, C.E.; Elsohly, M.A.; Boeren, E.G. Constituents of Cannabis sativa L. XVII. A review of the natural constituents. J. Nat. Prod. 1980, 43, 169-234. [CrossRef] [PubMed]

7. Bauer, R.; Woelkart, K.; Salo-Ahen, M.H.O. CB Receptor Ligands from Plants. Curr. Top. Med. Chem. 2008, 8, 173-186. [CrossRef]

8. Raduner, S.; Majewska, A.; Chen, J.Z.; Xie, X.Q.; Hamon, J.; Faller, B.; Altmann, K.H.; Gertsch, J. Alkylamides from Echinacea are a new class of cannabinomimetics. Cannabinoid type 2 receptor-dependent and -independent immunomodulatory effects. J. Biol. Chem. 2006, 281, 14192-14206. [CrossRef]

9. Malaca, S.; Busardò, F.P.; Nittari, G.; Sirignano, A.; Ricci, G. Fourth generation of synthetic cannabinoid receptor agonists: A review on the latest insights. Curr. Pharm. Des. 2021. [CrossRef]

10. Fantegrossi, W.E.; Moran, J.H.; Radominska-Pandya, A.; Prather, P.L. Distinct pharmacology and metabolism of K2 synthetic cannabinoids compared to $\triangle$ (9)-THC: Mechanism underlying greater toxicity? Life Sci. 2014, 97, 45-54. [CrossRef]

11. Burstein, S. Ajulemic acid (IP-751): Synthesis, proof of principle, toxicity studies, and clinical trials. AAPS J. 2005, 7, E143-E148. [CrossRef]

12. Corroon, J.; Phillips, J.A. A Cross-Sectional Study of Cannabidiol Users. Cannabis Cannabinoid Res. 2018, 3, 152-161. [CrossRef]

13. Peres, F.F.; Lima, A.C.; Hallak, J.E.C.; Crippa, J.A.; Silva, R.H.; Abílio, V.C. Cannabidiol as a Promising Strategy to Treat and Prevent Movement Disorders? Front. Pharmacol. 2018, 9, 482. [CrossRef] [PubMed]

14. Nachnani, R.; Raup-Konsavage, W.M.; Vrana, K.E. The Pharmacological Case for Cannabigerol. J. Pharmacol. Exp. Ther. 2021, 376, 204-212. [CrossRef] [PubMed]

15. Mechoulam, R. Plant cannabinoids: A neglected pharmacological treasure trove. Br. J. Pharmacol. 2005, 146, 913-915. [CrossRef]

16. Fischer, B.; Lee, A.; Robinson, T.; Hall, W. An overview of select cannabis use and supply indicators pre- and post-legalization in Canada. Subst. Abus. Treat. Prev. Policy 2021, 16, 77. [CrossRef]

17. Goodman, S.; Wadsworth, E.; Leos-Toro, C.; Hammond, D. Prevalence and forms of cannabis use in legal vs. illegal recreational cannabis markets. Int. J. Drug Policy 2020, 76, 102658. [CrossRef]

18. Freeman, T.P.; Groshkova, T.; Cunningham, A.; Sedefov, R.; Griffiths, P.; Lynskey, M.T. Increasing potency and price of cannabis in Europe, 2006-16. Addiction 2019, 114, 1015-1023. [CrossRef]

19. Freeman, T.P.; Craft, S.; Wilson, J.; Stylianou, S.; ElSohly, M.; Di Forti, M.; Lynskey, M.T. Changes in delta-9-tetrahydrocannabinol (THC) and cannabidiol (CBD) concentrations in cannabis over time: Systematic review and meta-analysis. Addiction 2021, 116, 1000-1010. [CrossRef]

20. Niesink, R.J.; Rigter, S.; Koeter, M.W.; Brunt, T.M. Potency trends of $\Delta$ 9-tetrahydrocannabinol, cannabidiol and cannabinol in cannabis in the Netherlands: 2005-15. Addiction 2015, 110, 1941-1950. [CrossRef] [PubMed]

21. Jetly, R.; Heber, A.; Fraser, G.; Boisvert, D. The efficacy of nabilone, a synthetic cannabinoid, in the treatment of PTSD-associated nightmares: A preliminary randomized, double-blind, placebo-controlled cross-over design study. Psychoneuroendocrinology 2015, 51, 585-588. [CrossRef] [PubMed]

22. Wilkinson, S.T.; Radhakrishnan, R.; D'Souza, D.C. A Systematic Review of the Evidence for Medical Marijuana in Psychiatric Indications. J. Clin. Psychiatry 2016, 77, 1050-1064. [CrossRef]

23. Timler, A.; Bulsara, C.; Bulsara, M.; Vickery, A.; Smith, J.; Codde, J. Use of cannabinoid-based medicine among older residential care recipients diagnosed with dementia: Study protocol for a double-blind randomised crossover trial. Trials 2020, 21, 188. [CrossRef]

24. Choi, N.G.; DiNitto, D.M.; Marti, C.N. Nonmedical versus medical marijuana use among three age groups of adults: Associations with mental and physical health status. Am. J. Addict. 2017, 26, 697-706. [CrossRef]

25. Mikos, R.A.; Kam, C.D. Has the "M" word been framed? Marijuana, cannabis, and public opinion. PLoS ONE 2019, 14, e0224289. [CrossRef] [PubMed]

26. Cohen, P.J. Medical marijuana: The conflict between scientific evidence and political ideology. Part two of two. J. Pain Palliat. Care Pharmacother. 2009, 23, 120-140. [CrossRef]

27. Hall, W.; Stjepanović, D.; Caulkins, J.; Lynskey, M.; Leung, J.; Campbell, G.; Degenhardt, L. Public health implications of legalising the production and sale of cannabis for medicinal and recreational use. Lancet 2019, 394, 1580-1590. [CrossRef]

28. Shover, C.L.; Humphreys, K. Six policy lessons relevant to cannabis legalization. Am. J. Drug Alcohol Abus. 2019, 45, 698-706. [CrossRef]

29. Ciolino, L.A.; Ranieri, T.L.; Brueggemeyer, J.L.; Taylor, A.M.; Mohrhaus, A.S. EVALI Vaping Liquids Part 1: GC-MS Cannabinoids Profiles and Identification of Unnatural THC Isomers. Front. Chem. 2021, 9, 746479. [CrossRef]

30. Duchateau, C.; Canfyn, M.; Desmedt, B.; Kauffmann, J.M.; Stévigny, C.; De Braekeleer, K.; Deconinck, E. CBD oils on the Belgian market: A validated MRM GC-MS/MS method for routine quality control using QuEChERS sample clean up. J. Pharm. Biomed. Anal. 2021, 205, 114344. [CrossRef]

31. Gloss, D. An Overview of Products and Bias in Research. Neurotherapeutics 2015, 12, 731-734. [CrossRef]

32. Koppel, B.S.; Brust, J.C.; Fife, T.; Bronstein, J.; Youssof, S.; Gronseth, G.; Gloss, D. Systematic review: Efficacy and safety of medical marijuana in selected neurologic disorders: Report of the Guideline Development Subcommittee of the American Academy of Neurology. Neurology 2014, 82, 1556-1563. [CrossRef] 
33. Ghosh, T.S.; Van Dyke, M.; Maffey, A.; Whitley, E.; Erpelding, D.; Wolk, L. Medical marijuana's public health lessons-Implications for retail marijuana in Colorado. N. Engl. J. Med. 2015, 372, 991-993. [CrossRef]

34. Okie, S. Medical marijuana and the Supreme Court. N. Engl. J. Med. 2005, 353, 648-651. [CrossRef]

35. Pijlman, F.T.; Rigter, S.M.; Hoek, J.; Goldschmidt, H.M.; Niesink, R.J. Strong increase in total delta-THC in cannabis preparations sold in Dutch coffee shops. Addict. Biol. 2005, 10, 171-180. [CrossRef]

36. Cascini, F.; Aiello, C.; Di Tanna, G. Increasing delta-9-tetrahydrocannabinol ( $\Delta-9-\mathrm{THC})$ content in herbal cannabis over time: Systematic review and meta-analysis. Curr. Drug Abus. Rev. 2012, 5, 32-40. [CrossRef]

37. Kahan, M.; Srivastava, A.; Clarke, S. Cannabis industry and medical cannabis clinics need regulation. Can. Fam. Physician 2019, $65,864-868$.

38. Ryan, J.E.; McCabe, S.E.; Boyd, C.J. Medicinal Cannabis: Policy, Patients, and Providers. Policy Politics Nurs. Pract. 2021, 22, 126-133. [CrossRef] [PubMed]

39. Kalaba, M.; Ware, M.A. Cannabinoid Profiles in Medical Cannabis Users: Effects of Age, Gender, Symptoms, and Duration of Use Cannabis Cannabinoid Res. 2021. ahead of print. [CrossRef] [PubMed]

40. Rapin, L.; Gamaoun, R.; El Hage, C.; Arboleda, M.F.; Prosk, E. Cannabidiol use and effectiveness: Real-world evidence from a Canadian medical cannabis clinic. J. Cannabis Res. 2021, 3, 19. [CrossRef] [PubMed]

41. Paul, B.D.; Jacobs, A. Effects of oxidizing adulterants on detection of 11-nor-delta9-THC-9-carboxylic acid in urine. J. Anal. Toxicol. 2002, 26, 460-463. [CrossRef]

42. Żubrycka, A.; Kwaśnica, A.; Haczkiewicz, M.; Sipa, K.; Rudnicki, K.; Skrzypek, S.; Poltorak, L. Illicit drugs street samples and their cutting agents. The result of the GC-MS based profiling define the guidelines for sensors development. Talanta 2022, 237, 122904. [CrossRef] [PubMed]

43. Giorgetti, A.; Busardò, F.P.; Tittarelli, R.; Auwärter, V.; Giorgetti, R. Post-Mortem Toxicology: A Systematic Review of Death Cases Involving Synthetic Cannabinoid Receptor Agonists. Front. Psychiatry 2020, 11, 464. [CrossRef]

44. Szaflarski, M.; Hansen, B.; Bebin, E.M.; Szaflarski, J.P. Social correlates of health status, quality of life, and mood states in patients treated with cannabidiol for epilepsy. Epilepsy Behav. 2017, 70, 364-369. [CrossRef]

45. Alkabbani, W.; Marrie, R.A.; Bugden, S.; Alessi-Severini, S.; Bolton, J.M.; Daeninck, P.; Leong, C. Persistence of use of prescribed cannabinoid medicines in Manitoba, Canada: A population-based cohort study. Addiction 2019, 114, 1791-1799. [CrossRef] [PubMed]

46. Charitonidi, E.; Studer, J.; Gaume, J.; Gmel, G.; Daeppen, J.B.; Bertholet, N. Socioeconomic status and substance use among Swiss young men: A population-based cross-sectional study. BMC Public Health 2016, 16, 333. [CrossRef] [PubMed]

47. Keating, G.M. Delta-9-Tetrahydrocannabinol/Cannabidiol Oromucosal Spray $\left(\right.$ Sativex $\left.{ }^{\circledR}\right)$ : A Review in Multiple Sclerosis-Related Spasticity. Drugs 2017, 77, 563-574. [CrossRef]

48. Badowski, M.E. A review of oral cannabinoids and medical marijuana for the treatment of chemotherapy-induced nausea and vomiting: A focus on pharmacokinetic variability and pharmacodynamics. Cancer Chemother. Pharmacol. 2017, 80, 441-449. [CrossRef] [PubMed]

49. Abu-Sawwa, R.; Stehling, C. Epidiolex (Cannabidiol) Primer: Frequently Asked Questions for Patients and Caregivers. J. Pediatric Pharmacol. Ther. 2020, 25, 75-77. [CrossRef] [PubMed]

50. Gelfand, E.V.; Cannon, C.P. Rimonabant: A selective blocker of the cannabinoid CB1 receptors for the management of obesity, smoking cessation and cardiometabolic risk factors. Expert Opin. Investig. Drugs 2006, 15, 307-315. [CrossRef]

51. Echeverria-Villalobos, M.; Todeschini, A.B.; Stoicea, N.; Fiorda-Diaz, J.; Weaver, T.; Bergese, S.D. Perioperative care of cannabis users: A comprehensive review of pharmacological and anesthetic considerations. J. Clin. Anesth. 2019, 57, 41-49. [CrossRef]

52. Flannery, K.M.; D'Souza, G.; Agarwal, R. Perioperative Management of the Pediatric Patient on Medicinal Marijuana: What Anesthesiologists Should Know. Anesth. Analg. 2019, 129, 1339-1343. [CrossRef]

53. Sutin, K.M.; Nahas, G.G. Physiological and Pharmacological Interactions of Marihuana (THC) with Drugs and Anesthetics. In Marihuana and Medicine; Nahas, G.G., Sutin, K.M., Harvey, D., Agurell, S., Pace, N., Cancro, R., Eds.; Humana Press: Totowa, NJ, USA, 1999; pp. 253-271.

54. Sommano, S.R.; Chittasupho, C.; Ruksiriwanich, W.; Jantrawut, P. The Cannabis Terpenes. Molecules 2020, 25, 5792. [CrossRef]

55. Parker, L.A.; Rock, E.M.; Limebeer, C.L. Regulation of nausea and vomiting by cannabinoids. Br. J. Pharmacol. 2011, 163, 1411-1422. [CrossRef]

56. Lee, C.Y.; Wey, S.P.; Liao, M.H.; Hsu, W.L.; Wu, H.Y.; Jan, T.R. A comparative study on cannabidiol-induced apoptosis in murine thymocytes and EL-4 thymoma cells. Int. Immunopharmacol. 2008, 8, 732-740. [CrossRef]

57. Sangiovanni, E.; Fumagalli, M.; Pacchetti, B.; Piazza, S.; Magnavacca, A.; Khalilpour, S.; Melzi, G.; Martinelli, G.; Dell'Agli, M. Cannabis sativa L. extract and cannabidiol inhibit in vitro mediators of skin inflammation and wound injury. Phytother. Res. 2019, 33, 2083-2093. [CrossRef] [PubMed]

58. Babalonis, S.; Raup-Konsavage, W.M.; Akpunonu, P.D.; Balla, A.; Vrana, K.E. $\Delta$ (8)-THC: Legal Status, Widespread Availability, and Safety Concerns. Cannabis Cannabinoid Res. 2021, 6, 362-365.

59. Hur, K.H.; Ma, S.X.; Lee, B.R.; Ko, Y.H.; Seo, J.Y.; Ryu, H.W.; Kim, H.J.; Yoon, S.; Lee, Y.S.; Lee, S.Y.; et al. Abuse Potential of Synthetic Cannabinoids: AM-1248, CB-13, and PB-22. Biomol. Ther. 2021, 29, 384-391. [CrossRef] [PubMed]

60. Key Substance Use and Mental Health Indicators in the United States: Results from the 2018 National Survey on Drug Use and Health; Substance Abuse and Mental Health Services Administration: Rockville, MD, USA, 2019. 
61. Bachhuber, M.A.; Saloner, B.; Cunningham, C.O.; Barry, C.L. Medical cannabis laws and opioid analgesic overdose mortality in the United States, 1999-2010. JAMA Intern. Med. 2014, 174, 1668-1673. [CrossRef] [PubMed]

62. Smith, D.M.; Goniewicz, M.L. E-cigarette or vaping product use-associated lung injury and state-level cannabis policies. $J$. Cannabis Res. 2020, 2, 45. [CrossRef]

63. Hall, W.; Lynskey, M. Assessing the public health impacts of legalizing recreational cannabis use: The US experience. World Psychiatry 2020, 19, 179-186. [CrossRef] [PubMed]

64. Duarte, R.A.; Dahmer, S.; Sanguinetti, S.Y.; Forde, G.; Duarte, D.P.; Kobak, L.F. Medical Cannabis for Headache Pain: A Primer for Clinicians. Curr. Pain Headache Rep. 2021, 25, 64. [CrossRef] [PubMed]

65. Akpunonu, P.; Baum, R.A.; Reckers, A.; Davidson, B.; Ellison, R.; Riley, M.; Trecki, J.; Gerona, R. Sedation and Acute Encephalopathy in a Pediatric Patient Following Ingestion of Delta-8-Tetrahydrocannabinol Gummies. Am. J. Case Rep. 2021, 22, e933488. [CrossRef]

66. Mehamha, H.; Doudka, N.; Minodier, P.; Néant, N.; Lacarelle, B.; Solas, C.; Fabresse, N. Unintentional cannabis poisoning in toddlers: A one year study in Marseille. Forensic Sci. Int. 2021, 325, 110858. [CrossRef]

67. Marijuana Symptoms and Warning Signs-Addiction Center. Available online: https://www.addictioncenter.com/drugs/ marijuana/symptoms-signs / (accessed on 10 July 2021).

68. Fitzgerald, K.T.; Bronstein, A.C.; Newquist, K.L. Marijuana poisoning. Top. Companion Anim. Med. 2013, 28, 8-12. [CrossRef]

69. Dach, J.; Moore, E.A.; Kander, J. Cannabis Extracts in Medicine: The Promise of Benefits in Seizure Disorders, Cancer and Other Conditions; McFarland Publisher: Jefferson, CA, USA, 2015.

70. Bramness, J.G.; von Soest, T. A longitudinal study of cannabis use increasing the use of asthma medication in young Norwegian adults. BMC Pulm. Med. 2019, 19, 52. [CrossRef] [PubMed]

71. Estévez-Lamorte, N.; Foster, S.; Gmel, G.; Mohler-Kuo, M. Routes of Administration of Illicit Drugs among Young Swiss Men: Their Prevalence and Associated Socio-Demographic Characteristics and Adverse Outcomes. Int. J. Environ. Res. Public Health 2021, 18, 11158. [CrossRef]

72. Russell, C.; Rueda, S.; Room, R.; Tyndall, M.; Fischer, B. Routes of administration for cannabis use-Basic prevalence and related health outcomes: A scoping review and synthesis. Int. J. Drug Policy 2018, 52, 87-96. [CrossRef]

73. Steigerwald, S.; Wong, P.O.; Cohen, B.E.; Ishida, J.H.; Vali, M.; Madden, E.; Keyhani, S. Smoking, Vaping, and Use of Edibles and Other Forms of Marijuana Among U.S. Adults. Ann. Intern. Med. 2018, 169, 890-892. [CrossRef]

74. Rosenberg, E.C.; Patra, P.H.; Whalley, B.J. Therapeutic effects of cannabinoids in animal models of seizures, epilepsy, epileptogenesis, and epilepsy-related neuroprotection. Epilepsy Behav. 2017, 70, 319-327. [CrossRef]

75. Morales, P.; Hurst, D.P.; Reggio, P.H. Molecular Targets of the Phytocannabinoids: A Complex Picture. Prog. Chem. Org. Nat. Prod. 2017, 103, 103-131.

76. Huestis, M.A. Human cannabinoid pharmacokinetics. Chem. Biodivers. 2007, 4, 1770-1804. [CrossRef]

77. Ng, T.; Gupta, V. Tetrahydrocannabinol (THC). In StatPearls; StatPearls Publishing LLC.: Treasure Island, FL, USA, 2021.

78. Martin-Santos, R.; Crippa, J.A.; Batalla, A.; Bhattacharyya, S.; Atakan, Z.; Borgwardt, S.; Allen, P.; Seal, M.; Langohr, K.; Farré, M.; et al. Acute effects of a single, oral dose of d9-tetrahydrocannabinol (THC) and cannabidiol (CBD) administration in healthy volunteers. Curr. Pharm. Des. 2012, 18, 4966-4979. [CrossRef]

79. Mlost, J.; Bryk, M.; Starowicz, K. Cannabidiol for Pain Treatment: Focus on Pharmacology and Mechanism of Action. Int. J. Mol. Sci. 2020, 21, 8870. [CrossRef]

80. Nelson, K.M.; Bisson, J.; Singh, G.; Graham, J.G.; Chen, S.N.; Friesen, J.B.; Dahlin, J.L.; Niemitz, M.; Walters, M.A.; Pauli, G.F. The Essential Medicinal Chemistry of Cannabidiol (CBD). J. Med. Chem. 2020, 63, 12137-12155. [CrossRef]

81. Quarles, W.; Ellman, G.; Jones, R. Toxicology of Marijuana: Conditions for Conversion of Cannabidioi to THC upon Smoking. Clin. Toxicol. 1973, 6, 211-216. [CrossRef] [PubMed]

82. Tashkin, D.P.; Gliederer, F.; Rose, J.; Change, P.; Hui, K.K.; Yu, J.L.; Wu, T.C. Effects of varying marijuana smoking profile on deposition of tar and absorption of CO and delta-9-THC. Pharmacol. Biochem. Behav. 1991, 40, 651-656. [CrossRef]

83. Czégény, Z.; Nagy, G.; Babinszki, B.; Bajtel, Á.; Sebestyén, Z.; Kiss, T.; Csupor-Löffler, B.; Tóth, B.; Csupor, D. CBD, a precursor of THC in e-cigarettes. Sci. Rep. 2021, 11, 8951. [CrossRef]

84. Karniol, I.G.; Shirakawa, I.; Takahashi, R.N.; Knobel, E.; Musty, R.E. Effects of $\Delta^{9}$-Tetrahydrocannabinol and Cannabinol in Man. Pharmacology 1975, 13, 502-512. [CrossRef] [PubMed]

85. Udoh, M.; Santiago, M.; Devenish, S.; McGregor, I.S.; Connor, M. Cannabichromene is a cannabinoid CB $\mathrm{CB}_{2}$ receptor agonist. Br. J. Pharmacol. 2019, 176, 4537-4547. [CrossRef] [PubMed]

86. Merkus, F.W.H.M. Cannabivarin and Tetrahydrocannabivarin, Two New Constituents of Hashish. Nature 1971, 232, 579-580. [CrossRef]

87. Turner, C.E.; Cheng, P.C.; Lewis, G.S.; Russell, M.H.; Sharma, G.K. Constituents of Cannabis sativa. Planta Med. 1979, 37, $217-225$. [CrossRef]

88. Pertwee, R.G. The diverse CB1 and CB2 receptor pharmacology of three plant cannabinoids: Delta9-tetrahydrocannabinol, cannabidiol and delta9-tetrahydrocannabivarin. Br. J. Pharmacol. 2008, 153, 199-215. [CrossRef] [PubMed]

89. Sekar, K.; Pack, A. Epidiolex as adjunct therapy for treatment of refractory epilepsy: A comprehensive review with a focus on adverse effects. F1000Reserch 2019, 8, F1000. [CrossRef] 
90. Thiele, E.A.; Marsh, E.D.; French, J.A.; Mazurkiewicz-Beldzinska, M.; Benbadis, S.R.; Joshi, C.; Lyons, P.D.; Taylor, A.; Roberts, C.; Sommerville, K. Cannabidiol in patients with seizures associated with Lennox-Gastaut syndrome (GWPCARE4): A randomised, double-blind, placebo-controlled phase 3 trial. Lancet 2018, 391, 1085-1096. [CrossRef]

91. Devinsky, O.; Cross, J.H.; Laux, L.; Marsh, E.; Miller, I.; Nabbout, R.; Scheffer, I.E.; Thiele, E.A.; Wright, S. Trial of Cannabidiol for Drug-Resistant Seizures in the Dravet Syndrome. N. Engl. J. Med. 2017, 376, 2011-2020. [CrossRef]

92. Hasenoehrl, C.; Storr, M.; Schicho, R. Cannabinoids for treating inflammatory bowel diseases: Where are we and where do we go? Expert Rev. Gastroenterol. Hepatol. 2017, 11, 329-337. [CrossRef]

93. Thomas, A.; Stevenson, L.A.; Wease, K.N.; Price, M.R.; Baillie, G.; Ross, R.A.; Pertwee, R.G. Evidence that the plant cannabinoid Delta9-tetrahydrocannabivarin is a cannabinoid CB1 and CB2 receptor antagonist. Br. J. Pharmacol. 2005, 146, 917-926. [CrossRef] [PubMed]

94. Cascio, M.G.; Gauson, L.A.; Stevenson, L.A.; Ross, R.A.; Pertwee, R.G. Evidence that the plant cannabinoid cannabigerol is a highly potent alpha2-adrenoceptor agonist and moderately potent 5HT1A receptor antagonist. Br. J. Pharmacol. 2010, 159, 129-141. [CrossRef]

95. Peball, M.; Krismer, F.; Knaus, H.G.; Djamshidian, A.; Werkmann, M.; Carbone, F.; Ellmerer, P.; Heim, B.; Marini, K.; Valent, D.; et al. Non-Motor Symptoms in Parkinson's Disease are Reduced by Nabilone. Ann. Neurol. 2020, 88, 712-722. [CrossRef]

96. Ruthirakuhan, M.T.; Herrmann, N.; Gallagher, D.; Andreazza, A.C.; Kiss, A.; Verhoeff, N.; Black, S.E.; Lanctôt, K.L. Investigating the safety and efficacy of nabilone for the treatment of agitation in patients with moderate-to-severe Alzheimer's disease: Study protocol for a cross-over randomized controlled trial. Contemp. Clin. Trials Commun. 2019, 15, 100385. [CrossRef]

97. Cunningham, D.; Bradley, C.J.; Forrest, G.J.; Hutcheon, A.W.; Adams, L.; Sneddon, M.; Harding, M.; Kerr, D.J.; Soukop, M.; Kaye, S.B. A randomized trial of oral nabilone and prochlorperazine compared to intravenous metoclopramide and dexamethasone in the treatment of nausea and vomiting induced by chemotherapy regimens containing cisplatin or cisplatin analogues. Eur. $J$. Cancer Clin. Oncol. 1988, 24, 685-689. [CrossRef]

98. GONG Jr, H.; TASHKIN, D.P.; CALVARESE, B. Comparison of bronchial effects of nabilone and terbutaline in healthy and asthmatic subjects. J. Clin. Pharmacol. 1983, 23, 127-133. [CrossRef] [PubMed]

99. Wissel, J.; Haydn, T.; Müller, J.; Brenneis, C.; Berger, T.; Poewe, W.; Schelosky, L.D. Low dose treatment with the synthetic cannabinoid Nabilone significantly reduces spasticity-related pain. J. Neurol. 2006, 253, 1337-1341. [CrossRef] [PubMed]

100. Tsang, C.C.; Giudice, M.G. Nabilone for the Management of Pain. Pharmacotherapy 2016, 36, 273-286. [CrossRef] [PubMed]

101. Turcott, J.G.; Del Rocío Guillen Núñez, M.; Flores-Estrada, D.; Oñate-Ocaña, L.F.; Zatarain-Barrón, Z.L.; Barrón, F.; Arrieta, O. The effect of nabilone on appetite, nutritional status, and quality of life in lung cancer patients: A randomized, double-blind clinical trial. Support Care Cancer 2018, 26, 3029-3038. [CrossRef]

102. Conte, A.; Vila Silván, C. Review of available data for the efficacy and effectiveness of nabiximols oromucosal spray (Sativex) in multiple sclerosis patients with moderate to severe spasticity. Neuro-Degener. Dis. 2021. [CrossRef]

103. Badowski, M.E.; Yanful, P.K. Dronabinol oral solution in the management of anorexia and weight loss in AIDS and cancer. Ther. Clin. Risk Manag. 2018, 14, 643-651. [CrossRef]

104. Bar-Sela, G.; Zalman, D.; Semenysty, V.; Ballan, E. The Effects of Dosage-Controlled Cannabis Capsules on Cancer-Related Cachexia and Anorexia Syndrome in Advanced Cancer Patients: Pilot Study. Integr. Cancer Ther. 2019, 18, 1534735419881498. [CrossRef]

105. Strasser, F.; Luftner, D.; Possinger, K.; Ernst, G.; Ruhstaller, T.; Meissner, W.; Ko, Y.D.; Schnelle, M.; Reif, M.; Cerny, T. Comparison of orally administered cannabis extract and delta-9-tetrahydrocannabinol in treating patients with cancer-related anorexia-cachexia syndrome: A multicenter, phase III, randomized, double-blind, placebo-controlled clinical trial from the Cannabis-In-CachexiaStudy-Group. J. Clin. Oncol. 2006, 24, 3394-3400.

106. Carley, D.W.; Prasad, B.; Reid, K.J.; Malkani, R.; Attarian, H.; Abbott, S.M.; Vern, B.; Xie, H.; Yuan, C.; Zee, P.C. Pharmacotherapy of Apnea by Cannabimimetic Enhancement, the PACE Clinical Trial: Effects of Dronabinol in Obstructive Sleep Apnea. Sleep 2018, 41, zsx184. [CrossRef]

107. Spanagel, R.; Bilbao, A. Approved cannabinoids for medical purposes-Comparative systematic review and meta-analysis for sleep and appetite. Neuropharmacology 2021, 196, 108680. [CrossRef]

108. Zhao, L.; Liu, T.; Dou, Z.J.; Wang, M.T.; Hu, Z.X.; Wang, B. CB1 receptor antagonist rimonabant protects against chronic intermittent hypoxia-induced renal injury in rats. BMC Nephrol. 2021, 22, 153. [CrossRef] [PubMed]

109. Huestis, M.A.; Boyd, S.J.; Heishman, S.J.; Preston, K.L.; Bonnet, D.; Le Fur, G.; Gorelick, D.A. Single and multiple doses of rimonabant antagonize acute effects of smoked cannabis in male cannabis users. Psychopharmacology 2007, 194, 505-515. [CrossRef] [PubMed]

110. Traynor, K. Panel advises against rimonabant approval. Am. J. Health Syst. Pharm. 2007, 64, 1460-1461. [CrossRef]

111. Meuth, S.G.; Henze, T.; Essner, U.; Trompke, C.; Vila Silván, C. Tetrahydrocannabinol and cannabidiol oromucosal spray in resistant multiple sclerosis spasticity: Consistency of response across subgroups from the SAVANT randomized clinical trial. Int. J. Neurosci. 2020, 130, 1199-1205. [CrossRef]

112. Bennici, A.; Mannucci, C.; Calapai, F.; Cardia, L.; Ammendolia, I.; Gangemi, S.; Calapai, G.; Griscti Soler, D. Safety of Medical Cannabis in Neuropathic Chronic Pain Management. Molecules 2021, 26, 6257. [CrossRef]

113. Walitt, B.; Klose, P.; Fitzcharles, M.A.; Phillips, T.; Häuser, W. Cannabinoids for fibromyalgia. Cochrane Database Syst. Rev. 2016, 7, Cd011694. 
114. Ward, S.J.; Lichtman, A.H.; Piomelli, D.; Parker, L.A. Cannabinoids and Cancer Chemotherapy-Associated Adverse Effects. J. Natl. Cancer Inst. Monogr. 2021, 2021, 78-85. [CrossRef]

115. Charernboon, T.; Lerthattasilp, T.; Supasitthumrong, T. Effectiveness of Cannabinoids for Treatment of Dementia: A Systematic Review of Randomized Controlled Trials. Clin. Gerontol. 2021, 44, 16-24. [CrossRef] [PubMed]

116. Haspula, D.; Clark, M.A. Cannabinoid Receptors: An Update on Cell Signaling, Pathophysiological Roles and Therapeutic Opportunities in Neurological, Cardiovascular, and Inflammatory Diseases. Int. J. Mol. Sci. 2020, 21, 7693. [CrossRef]

117. Pertwee, R.G.; Ross, R.A. Cannabinoid receptors and their ligands. Prostaglandins Leukot. Essent. Fat. Acids 2002, 66, 101-121. [CrossRef] [PubMed]

118. Alsalem, M.; Haddad, M.; Aldossary, S.A.; Kalbouneh, H.; Altarifi, A.; Jaffal, S.M.; Abbas, M.A.; Aldaoud, N.; El-Salem, K. Role of cannabinoid receptor 1 and the peroxisome proliferator-activated receptor $\alpha$ in mediating anti-nociceptive effects of synthetic cannabinoids and a cannabinoid-like compound. Inflammopharmacology 2019, 27, 1131-1142. [CrossRef] [PubMed]

119. Cooper, Z.D.; Haney, M. Cannabis reinforcement and dependence: Role of the cannabinoid CB1 receptor. Addict. Biol. 2008, 13, 188-195. [CrossRef] [PubMed]

120. Lowin, T.; Straub, R.H. Cannabinoid-based drugs targeting CB1 and TRPV1, the sympathetic nervous system, and arthritis. Arthritis Res. Ther. 2015, 17, 226. [CrossRef] [PubMed]

121. Nguyen, P.T.; Schmid, C.L.; Raehal, K.M.; Selley, D.E.; Bohn, L.M.; Sim-Selley, L.J. $\beta$-arrestin2 regulates cannabinoid CB1 receptor signaling and adaptation in a central nervous system region-dependent manner. Biol. Psychiatry 2012, 71, 714-724. [CrossRef]

122. Ashton, J.C.; Hancox, R.J. The Case for Cannabinoid CB1 Receptors as a Target for Bronchodilator Therapy for $\beta$-agonist Resistant Asthma. Curr. Drug Targets 2018, 19, 1344-1349. [CrossRef]

123. Panikashvili, D.; Mechoulam, R.; Beni, S.M.; Alexandrovich, A.; Shohami, E. CB1 cannabinoid receptors are involved in neuroprotection via NF-kappa B inhibition. J. Cereb. Blood Flow Metab. 2005, 25, 477-484. [CrossRef]

124. Leo, L.M.; Abood, M.E. CB1 Cannabinoid Receptor Signaling and Biased Signaling. Molecules 2021, 26, 5413. [CrossRef] [PubMed]

125. Karmaus, P.W.; Chen, W.; Kaplan, B.L.; Kaminski, N.E. $\Delta 9$-tetrahydrocannabinol suppresses cytotoxic T lymphocyte function independent of CB1 and CB 2, disrupting early activation events. J. Neuroimmune Pharmacol. 2012, 7, 843-855. [CrossRef]

126. Baldassarri, S.; Bertoni, A.; Bagarotti, A.; Sarasso, C.; Zanfa, M.; Catani, M.V.; Avigliano, L.; Maccarrone, M.; Torti, M.; Sinigaglia, F. The endocannabinoid 2-arachidonoylglycerol activates human platelets through non-CB1/CB2 receptors. J. Thromb. Haemost. 2008, 6, 1772-1779. [CrossRef] [PubMed]

127. Kanakis Jr, C.; Pouget, J.M.; Rosen, K. The effects of delta-9-tetrahydrocannabinol (cannabis) on cardiac performance with and without beta blockade. Circulation 1976, 53, 703-707. [CrossRef]

128. Graham, J.D.; Li, D.M. Cardiovascular and respiratory effects of cannabis in cat and rat. Br. J. Pharmacol. 1973, 49, 1-10. [CrossRef] [PubMed]

129. Beaconsfield, P.; Ginsburg, J.; Rainsbury, R. Marihuana smoking: Cardiovascular effects in man and possible mechanisms. N. Engl. J. Med. 1972, 287, 209-212. [CrossRef] [PubMed]

130. Shafaroodi, H.; Moezi, L.; Bahremand, A.; Dehpour, A.R. The role of $\alpha 2$-adrenoceptors in the anti-convulsant effects of cannabinoids on pentylenetetrazole-induced seizure threshold in mice. Eur. J. Pharmacol. 2013, 714, 1-6. [CrossRef]

131. Ma, D.; Rajakumaraswamy, N.; Maze, M. $\alpha 2$-Adrenoceptor agonists: Shedding light on neuroprotection? Br. Med. Bull. 2005, 71, 77-92. [CrossRef]

132. Zanelati, T.V.; Biojone, C.; Moreira, F.A.; Guimarães, F.S.; Joca, S.R. Antidepressant-like effects of cannabidiol in mice: Possible involvement of 5-HT1A receptors. Br. J. Pharmacol. 2010, 159, 122-128. [CrossRef]

133. Bolognini, D.; Rock, E.M.; Cluny, N.L.; Cascio, M.G.; Limebeer, C.L.; Duncan, M.; Stott, C.G.; Javid, F.A.; Parker, L.A.; Pertwee, R.G. Cannabidiolic acid prevents vomiting in Suncus murinus and nausea-induced behaviour in rats by enhancing 5-HT1A receptor activation. Br. J. Pharmacol. 2013, 168, 1456-1470. [CrossRef]

134. Gao, Y.; Liu, Y.; Zhu, K.; Zhang, Z.; Qiao, H.; Lu, Z.; Zhong, T.; Liu, Y.; Zhou, H. Blocking of TRPV-1 in the parodontium relieves orthodontic pain by inhibiting the expression of TRPV-1 in the trigeminal ganglion during experimental tooth movement in rats. Neurosci. Lett. 2016, 628, 67-72. [CrossRef]

135. Skaper, S.D. TRPV-ing up pain for a long life. CNS Neurol. Disord. Drug Targets 2014, 13, 926. [CrossRef]

136. Sato, J.; Segami, N.; Yoshitake, Y.; Kaneyama, K.; Abe, A.; Yoshimura, H.; Fujimura, K. Expression of capsaicin receptor TRPV-1 in synovial tissues of patients with symptomatic internal derangement of the temporomandibular joint and joint pain. Oral Surg. Oral Med. Oral Pathol. Oral Radiol. Endodontology 2005, 100, 674-681. [CrossRef]

137. Lakshmi, S.; Joshi, P.G. Co-activation of P2Y2 receptor and TRPV channel by ATP: Implications for ATP induced pain. Cell. Mol. Neurobiol. 2005, 25, 819-832. [CrossRef]

138. De Petrocellis, L.; Orlando, P.; Moriello, A.S.; Aviello, G.; Stott, C.; Izzo, A.A.; Di Marzo, V. Cannabinoid actions at TRPV channels: Effects on TRPV3 and TRPV4 and their potential relevance to gastrointestinal inflammation. Acta Physiol. 2012, 204, 255-266. [CrossRef] [PubMed]

139. Hamanaka, K.; Jian, M.Y.; Townsley, M.I.; King, J.A.; Liedtke, W.; Weber, D.S.; Eyal, F.G.; Clapp, M.M.; Parker, J.C. TRPV4 channels augment macrophage activation and ventilator-induced lung injury. Am. J. Physiol. Lung Cell. Mol. Physiol. 2010, 299, L353-L362. [CrossRef] 
140. Hamanaka, K.; Jian, M.Y.; Weber, D.S.; Alvarez, D.F.; Townsley, M.I.; Al-Mehdi, A.B.; King, J.A.; Liedtke, W.; Parker, J.C. TRPV4 initiates the acute calcium-dependent permeability increase during ventilator-induced lung injury in isolated mouse lungs. Am. J. Physiol. Lung Cell Mol. Physiol. 2007, 293, L923-L932. [CrossRef] [PubMed]

141. Starkus, J.; Jansen, C.; Shimoda, L.M.N.; Stokes, A.J.; Small-Howard, A.L.; Turner, H. Diverse TRPV1 responses to cannabinoids. Channels 2019, 13, 172-191. [CrossRef]

142. Filosa, J.A.; Yao, X.; Rath, G. TRPV4 and the regulation of vascular tone. J. Cardiovasc. Pharmacol. 2013, 61, 113-119. [CrossRef]

143. Rosenbaum, T.; Simon, S.A. Frontiers in Neuroscience. TRPV1 Receptors and Signal Transduction. In TRP Ion Channel Function in Sensory Transduction and Cellular Signaling Cascades; Liedtke, W.B., Heller, S., Eds.; Taylor \& Francis Group, LLC.: Boca Raton, FL, USA, 2007.

144. Foadi, N.; Leuwer, M.; Demir, R.; Dengler, R.; Buchholz, V.; de la Roche, J.; Karst, M.; Haeseler, G.; Ahrens, J. Lack of positive allosteric modulation of mutated alpha(1)S267I glycine receptors by cannabinoids. Naunyn. Schmiedebergs Arch. Pharmacol. 2010, 381, 477-482. [CrossRef]

145. Rojas, P.S.; Fiedler, J.L. What Do We Really Know About 5-HT1A Receptor Signaling in Neuronal Cells? Front. Cell. Neurosci. 2016, 10, 272. [CrossRef]

146. Yang, S.; Koo, D.J.; Chaudry, I.H.; Wang, P. Glycine attenuates hepatocellular depression during early sepsis and reduces sepsis-induced mortality. Crit. Care Med. 2001, 29, 1201-1206. [CrossRef] [PubMed]

147. Yao, L.; Wells, M.; Wu, X.; Xu, Y.; Zhang, L.; Xiong, W. Membrane cholesterol dependence of cannabinoid modulation of glycine receptor. FASEB J. 2020, 34, 10920-10930. [CrossRef]

148. Xiong, W.; Wu, X.; Li, F.; Cheng, K.; Rice, K.C.; Lovinger, D.M.; Zhang, L. A common molecular basis for exogenous and endogenous cannabinoid potentiation of glycine receptors. J. Neurosci. 2012, 32, 5200-5208. [CrossRef]

149. Oyagawa, C.R.M.; Grimsey, N.L. Cannabinoid receptor $\mathrm{CB}(1)$ and $\mathrm{CB}(2)$ interacting proteins: Techniques, progress and perspectives. Methods Cell Biol. 2021, 166, 83-132.

150. Pagotto, U.; Marsicano, G.; Cota, D.; Lutz, B.; Pasquali, R. The emerging role of the endocannabinoid system in endocrine regulation and energy balance. Endocr. Rev. 2006, 27, 73-100. [CrossRef]

151. Toczek, M.; Malinowska, B. Enhanced endocannabinoid tone as a potential target of pharmacotherapy. Life Sci. 2018, 204, 20-45. [CrossRef] [PubMed]

152. Kishimoto, Y.; Kano, M. Endogenous cannabinoid signaling through the CB1 receptor is essential for cerebellum-dependent discrete motor learning. J. Neurosci. 2006, 26, 8829-8837. [CrossRef] [PubMed]

153. Maldonado, R.; Valverde, O.; Berrendero, F. Involvement of the endocannabinoid system in drug addiction. Trends Neurosci. 2006, 29, 225-232. [CrossRef] [PubMed]

154. Zou, S.; Kumar, U. Cannabinoid Receptors and the Endocannabinoid System: Signaling and Function in the Central Nervous System. Int. J. Mol. Sci. 2018, 19, 833. [CrossRef]

155. Fonseca, B.M.; Costa, M.A.; Almada, M.; Correia-da-Silva, G.; Teixeira, N.A. Endogenous cannabinoids revisited: A biochemistry perspective. Prostaglandins Other Lipid Mediat. 2013, 102-103, 13-30. [CrossRef]

156. Navarrete, F.; García-Gutiérrez, M.S.; Gasparyan, A.; Navarro, D.; Manzanares, J. CB2 Receptor Involvement in the Treatment of Substance Use Disorders. Biomolecules 2021, 11, 1556. [CrossRef] [PubMed]

157. Fride, E. Endocannabinoids in the central nervous system-An overview. Prostaglandins Leukot. Essent. Fat. Acids 2002, 66, 221-233. [CrossRef] [PubMed]

158. Raïch, I.; Rivas-Santisteban, R.; Lillo, A.; Lillo, J.; Reyes-Resina, I.; Nadal, X.; Ferreiro-Vera, C.; de Medina, V.S.; Majellaro, M.; Sotelo, E.; et al. Similarities and differences upon binding of naturally occurring $\Delta^{9}$-tetrahydrocannabinol-derivatives to cannabinoid $\mathrm{CB}_{1}$ and $\mathrm{CB}_{2}$ receptors. Pharmacol. Res. 2021, 174, 105970. [CrossRef] [PubMed]

159. Espejo-Porras, F.; Fernández-Ruiz, J.; Pertwee, R.G.; Mechoulam, R.; García, C. Motor effects of the non-psychotropic phytocannabinoid cannabidiol that are mediated by 5-HT1A receptors. Neuropharmacology 2013, 75, 155-163. [CrossRef]

160. Rock, E.M.; Bolognini, D.; Limebeer, C.L.; Cascio, M.G.; Anavi-Goffer, S.; Fletcher, P.J.; Mechoulam, R.; Pertwee, R.G.; Parker, L.A Cannabidiol, a non-psychotropic component of cannabis, attenuates vomiting and nausea-like behaviour via indirect agonism of 5-HT(1A) somatodendritic autoreceptors in the dorsal raphe nucleus. Br. J. Pharmacol. 2012, 165, 2620-2634. [CrossRef]

161. Marinho, A.L.; Vila-Verde, C.; Fogaça, M.V.; Guimarães, F.S. Effects of intra-infralimbic prefrontal cortex injections of cannabidiol in the modulation of emotional behaviors in rats: Contribution of $5 \mathrm{HT}_{1 \mathrm{~A}}$ receptors and stressful experiences. Behav. Brain Res. 2015, 286, 49-56. [CrossRef] [PubMed]

162. Wang, R.; Xu, Y.; Wu, H.L.; Li, Y.B.; Li, Y.H.; Guo, J.B.; Li, X.J. The antidepressant effects of curcumin in the forced swimming test involve 5-HT1 and 5-HT2 receptors. Eur. J. Pharmacol. 2008, 578, 43-50. [CrossRef]

163. Johanek, L.M.; Heitmiller, D.R.; Turner, M.; Nader, N.; Hodges, J.; Simone, D.A. Cannabinoids attenuate capsaicin-evoked hyperalgesia through spinal and peripheral mechanisms. Pain 2001, 93, 303-315. [CrossRef]

164. de Sousa, D.P.; de Almeida Soares Hocayen, P.; Andrade, L.N.; Andreatini, R. A Systematic Review of the Anxiolytic-Like Effects of Essential Oils in Animal Models. Molecules 2015, 20, 18620-18660. [CrossRef]

165. Lewis, M.A.; Russo, E.B.; Smith, K.M. Pharmacological Foundations of Cannabis Chemovars. Planta Med. 2018, 84, 225-233. [CrossRef]

166. Colović, M.B.; Krstić, D.Z.; Lazarević-Pašti, T.D.; Bondžić, A.M.; Vasić, V.M. Acetylcholinesterase inhibitors: Pharmacology and toxicology. Curr. Neuropharmacol. 2013, 11, 315-335. [CrossRef] 
167. Salehi, B.; Upadhyay, S.; Erdogan Orhan, I.; Kumar Jugran, A.; Jayaweera, S.L.D.; Dias, D.A.; Sharopov, F.; Taheri, Y.; Martins, N.; Baghalpour, N.; et al. Therapeutic Potential of $\alpha$ - and $\beta$-Pinene: A Miracle Gift of Nature. Biomolecules 2019, 9, 738. [CrossRef]

168. Lucas, C.J.; Galettis, P.; Schneider, J. The pharmacokinetics and the pharmacodynamics of cannabinoids. Br. J. Clin. Pharmacol. 2018, 84, 2477-2482. [CrossRef]

169. McGilveray, I.J. Pharmacokinetics of cannabinoids. Pain Res. Manag. 2005, 10 (Suppl. A), 15a-22a. [CrossRef] [PubMed]

170. Wu, T.C.; Tashkin, D.P.; Djahed, B.; Rose, J.E. Pulmonary hazards of smoking marijuana as compared with tobacco. N. Engl. J. Med. 1988, 318, 347-351. [CrossRef] [PubMed]

171. Aronow, W.S.; Cassidy, J. Effect of smoking marihuana and of a high-nicotine cigarette on angina pectoris. Clin. Pharmacol. Ther. 1975, 17, 549-554. [CrossRef]

172. Lynch, J.; Lorenz, L.; Brueggemeyer, J.L.; Lanzarotta, A.; Falconer, T.M.; Wilson, R.A. Simultaneous Temperature Measurements and Aerosol Collection During Vaping for the Analysis of $\Delta^{9}$-Tetrahydrocannabinol and Vitamin E Acetate Mixtures in Ceramic Coil Style Cartridges. Front. Chem. 2021, 9, 734793. [CrossRef]

173. Rao, D.R.; Maple, K.L.; Dettori, A.; Afolabi, F.; Francis, J.K.R.; Artunduaga, M.; Lieu, T.J.; Aldy, K.; Cao, D.J.; Hsu, S.; et al. Clinical Features of E-cigarette, or Vaping, Product Use-Associated Lung Injury in Teenagers. Pediatrics 2020, 146, e20194104. [CrossRef] [PubMed]

174. Gaston, T.E.; Friedman, D. Pharmacology of cannabinoids in the treatment of epilepsy. Epilepsy Behav. 2017, 70, 313-318. [CrossRef]

175. Grotenhermen, F. Pharmacokinetics and pharmacodynamics of cannabinoids. Clin. Pharmacokinet. 2003, 42, 327-360. [CrossRef] [PubMed]

176. Martin, J.H.; Schneider, J.; Lucas, C.J.; Galettis, P. Exogenous Cannabinoid Efficacy: Merely a Pharmacokinetic Interaction? Clin. Pharmacokinet. 2018, 57, 539-545. [CrossRef]

177. Stinchcomb, A.L.; Valiveti, S.; Hammell, D.C.; Ramsey, D.R. Human skin permeation of Delta8-tetrahydrocannabinol, cannabidiol and cannabinol. J. Pharm. Pharmacol. 2004, 56, 291-297. [CrossRef]

178. Challapalli, P.V.; Stinchcomb, A.L. In vitro experiment optimization for measuring tetrahydrocannabinol skin permeation. Int. J. Pharm. 2002, 241, 329-339. [CrossRef]

179. Casati, S.; Angeli, I.; Ravelli, A.; Del Fabbro, M.; Minoli, M.; Orioli, M. 11-OH-THC in hair as marker of active cannabis consumption: Estimating a reliable cut-off by evaluation of 672 THC-positive hair samples. Forensic Sci. Int. $2019,304,109951$. [CrossRef]

180. Gonçalves, J.; Rosado, T.; Soares, S.; Simão, A.Y.; Caramelo, D.; Luís, Â.; Fernández, N.; Barroso, M.; Gallardo, E.; Duarte, A.P. Cannabis and Its Secondary Metabolites: Their Use as Therapeutic Drugs, Toxicological Aspects, and Analytical Determination. Medicines 2019, 6, 31. [CrossRef]

181. Childers, S.R. Activation of G-proteins in brain by endogenous and exogenous cannabinoids. Aaps. J. 2006, 8, E112-E117. [CrossRef]

182. Rubino, T.; Viganò, D.; Costa, B.; Colleoni, M.; Parolaro, D. Loss of cannabinoid-stimulated guanosine $5^{\prime}-O-\left(3-\left[{ }^{35} \mathrm{~S}\right] \mathrm{Thiotriphosphate)}\right.$ binding without receptor down-regulation in brain regions of anandamide-tolerant rats. J. Neurochem. 2000, 75, $2478-2484$. [CrossRef]

183. Selley, D.E.; Rorrer, W.K.; Breivogel, C.S.; Zimmer, A.M.; Zimmer, A.; Martin, B.R.; Sim-Selley, L.J. Agonist efficacy and receptor efficiency in heterozygous CB1 knockout mice: Relationship of reduced CB1 receptor density to G-protein activation. J. Neurochem. 2001, 77, 1048-1057. [CrossRef]

184. McKinney, D.L.; Cassidy, M.P.; Collier, L.M.; Martin, B.R.; Wiley, J.L.; Selley, D.E.; Sim-Selley, L.J. Dose-related differences in the regional pattern of cannabinoid receptor adaptation and in vivo tolerance development to delta9-tetrahydrocannabinol. $J$. Pharmacol. Exp. Ther. 2008, 324, 664-673. [CrossRef]

185. Kano, M.; Ohno-Shosaku, T.; Hashimotodani, Y.; Uchigashima, M.; Watanabe, M. Endocannabinoid-mediated control of synaptic transmission. Physiol. Rev. 2009, 89, 309-380. [CrossRef]

186. Stanley, C.P.; Hind, W.H.; Tufarelli, C.; O'Sullivan, S.E. The endocannabinoid anandamide causes endothelium-dependent vasorelaxation in human mesenteric arteries. Pharmacol. Res. 2016, 113, 356-363. [CrossRef]

187. Stanley, C.P.; Hind, W.H.; Tufarelli, C.; O'Sullivan, S.E. Cannabidiol causes endothelium-dependent vasorelaxation of human mesenteric arteries via $\mathrm{CB}_{1}$ activation. Cardiovasc. Res. 2015, 107, 568-578. [CrossRef]

188. Malinowska, B.; Baranowska-Kuczko, M.; Schlicker, E. Triphasic blood pressure responses to cannabinoids: Do we understand the mechanism? Br. J. Pharmacol. 2012, 165, 2073-2088. [CrossRef]

189. López-Dyck, E.; Andrade-Urzúa, F.; Elizalde, A.; Ferrer-Villada, T.; Dagnino-Acosta, A.; Huerta, M.; Osuna-Calleros, Z.; RangelSandoval, C.; Sánchez-Pastor, E. ACPA and JWH-133 modulate the vascular tone of superior mesenteric arteries through cannabinoid receptors, $\mathrm{BK}_{\mathrm{Ca}}$ channels, and nitric oxide dependent mechanisms. Pharmacol. Rep. 2017, 69, 1131-1139. [CrossRef]

190. López-Miranda, V.; Dannert, M.T.; Herradón, E.; Alsasua, A.; Martín, M.I. Cytochrome P450 pathway contributes to methanandamide-induced vasorelaxation in rat aorta. Cardiovasc. Drugs Ther. 2010, 24, 379-389. [CrossRef]

191. Sánchez-Pastor, E.; Andrade, F.; Sánchez-Pastor, J.M.; Elizalde, A.; Huerta, M.; Virgen-Ortiz, A.; Trujillo, X.; Rodríguez-Hernández, A. Cannabinoid receptor type 1 activation by arachidonylcyclopropylamide in rat aortic rings causes vasorelaxation involving calcium-activated potassium channel subunit alpha-1 and calcium channel, voltage-dependent, L type, alpha 1C subunit. Eur. J. Pharmacol. 2014, 729, 100-106. [CrossRef] 
192. Romano, M.R.; Lograno, M.D. Involvement of the peroxisome proliferator-activated receptor (PPAR) alpha in vascular response of endocannabinoids in the bovine ophthalmic artery. Eur. J. Pharmacol. 2012, 683, 197-203. [CrossRef]

193. O'Sullivan, S.E.; Tarling, E.J.; Bennett, A.J.; Kendall, D.A.; Randall, M.D. Novel time-dependent vascular actions of Delta9tetrahydrocannabinol mediated by peroxisome proliferator-activated receptor gamma. Biochem. Biophys. Res. Commun. 2005, 337, 824-831. [CrossRef] [PubMed]

194. Sánchez-Pastor, E.; Trujillo, X.; Ramos-Flores, C.; Ríos-Silva, M.; Andrade, F.; Cárdenas, Y.; Castro, E.; Urzúa, Z.; Newton-Sánchez, O.; Huerta, M. Type 2 Diabetes Alters Vascular Cannabinoid Receptor 1 Expression, Phosphorylation Status, and Vasorelaxation in Rat Aorta. Molecules 2020, 25, 4948. [CrossRef] [PubMed]

195. Wheal, A.J.; Randall, M.D. Effects of hypertension on vasorelaxation to endocannabinoids in vitro. Eur. J. Pharmacol. 2009, 603, 79-85. [CrossRef]

196. Wheal, A.J.; Bennett, T.; Randall, M.D.; Gardiner, S.M. Effects of chronic nitric oxide synthase inhibition on the cardiovascular responses to cannabinoids in vivo and in vitro. Br. J. Pharmacol. 2007, 150, 662-671. [CrossRef]

197. Wang, X.; Derakhshandeh, R.; Liu, J.; Narayan, S.; Nabavizadeh, P.; Le, S.; Danforth, O.M.; Pinnamaneni, K.; Rodriguez, H.J.; Luu, E.; et al. One Minute of Marijuana Secondhand Smoke Exposure Substantially Impairs Vascular Endothelial Function. J. Am. Heart Assoc. 2016, 5, e003858. [CrossRef]

198. Gregg, J.M.; Campbell, R.L.; Levin, K.J.; Ghia, J.; Elliott, R.A. Cardiovascular effects of cannabinol during oral surgery. Anesth. Analg. 1976, 55, 203-213. [CrossRef]

199. Johnstone, R.E.; Lief, P.L.; Kulp, R.A.; Smith, T.C. Combination of delta9-tetrahydrocannabinol with oxymorphone or pentobarbital: Effects on ventilatory control and cardiovascular dynamics. Anesthesiology 1975, 42, 674-684. [CrossRef]

200. Foltin, R.W.; Fischman, M.W.; Pedroso, J.J.; Pearlson, G.D. Marijuana and cocaine interactions in humans: Cardiovascular consequences. Pharmacol. Biochem. Behav. 1987, 28, 459-464. [CrossRef]

201. Bellville, J.W.; Gasser, J.C.; Miyake, T.; Aqleh, K. Tolerance to the respiratory effects of marijuana in man. J. Pharmacol. Exp. Ther. 1976, 197, 326-331.

202. Jandhyala, B.S. Effects of prolonged administration of delta 9-tetrahydrocannabinol on the autonomic and cardiovascular function and regional hemodynamics in mongrel dogs. Res. Commun. Chem. Pathol. Pharmacol. 1978, 20, 489-508.

203. Nash, E.; Roberts, D.M.; Jamshidi, N. Reverse Takotsubo Cardiomyopathy Precipitated by Chronic Cocaine and Cannabis Use. Cardiovasc. Toxicol. 2021, 21, 1012-1018. [CrossRef]

204. Ladha, K.S.; Mistry, N.; Wijeysundera, D.N.; Clarke, H.; Verma, S.; Hare, G.M.T.; Mazer, C.D. Recent cannabis use and myocardial infarction in young adults: A cross-sectional study. Can. Med Assoc. J. 2021, 193, E1377-E1384. [CrossRef]

205. Parekh, T.; Pemmasani, S.; Desai, R. Marijuana Use Among Young Adults (18-44 Years of Age) and Risk of Stroke: A Behavioral Risk Factor Surveillance System Survey Analysis. Stroke 2020, 51, 308-310. [CrossRef]

206. Zhao, J.; Chen, H.; Zhuo, C.; Xia, S. Cannabis Use and the Risk of Cardiovascular Diseases: A Mendelian Randomization Study. Front. Cardiovasc. Med. 2021, 8, 676850. [CrossRef]

207. Pacher, P.; Steffens, S.; Haskó, G.; Schindler, T.H.; Kunos, G. Cardiovascular effects of marijuana and synthetic cannabinoids: The good, the bad, and the ugly. Nat. Rev. Cardiol. 2018, 15, 151-166. [CrossRef]

208. Richards, J.R. Mechanisms for the Risk of Acute Coronary Syndrome and Arrhythmia Associated With Phytogenic and Synthetic Cannabinoid Use. J. Cardiovasc. Pharmacol. Ther. 2020, 25, 508-522. [CrossRef]

209. Banerjee, A.; Gandhi, A.B.; Antony, I.; Alexander, J.; Hisbulla, M.; Kannichamy, V.; Kaleem, I.; Mishra, V.; Khan, S. Role of Cannabis in the Incidence of Myocardial Infarction: A Review. Cureus 2020, 12, e11097. [CrossRef]

210. Singh, B.O.; Panda, P.K.; Walia, R. Recreational cannabis use causing non-ischaemic cardiomyopathy and cardioembolism in a young adult. BMJ Case Rep. 2021, 14, e243193. [CrossRef]

211. Fernandez-Galinski, S.; Bermejo, S.; Mansilla, R.; Pol, O.; Puig, M.M. Comparative assessment of the effects of alfentanil, esmolol or clonidine when used as adjuvants during induction of general anaesthesia. Eur. J. Anaesthesiol. 2004, 21, 476-482. [CrossRef]

212. Sulkowski, A.; Vachon, L.; Rich, E.S., Jr. Propranolol effects on acute marihuana intoxication in man. Psychopharmacology 1977, 52, 47-53. [CrossRef]

213. Scheau, C.; Caruntu, C.; Badarau, I.A.; Scheau, A.E.; Docea, A.O.; Calina, D.; Caruntu, A. Cannabinoids and Inflammations of the Gut-Lung-Skin Barrier. J. Pers. Med. 2021, 11, 494. [CrossRef]

214. Williams, S.J.; Hartley, J.P.; Graham, J.D. Bronchodilator effect of delta1-tetrahydrocannabinol administered by aerosol of asthmatic patients. Thorax 1976, 31, 720-723. [CrossRef]

215. Tashkin, D.P.; Shapiro, B.J.; Frank, I.M. Acute Pulmonary Physiologic Effects of Smoked Marijuana and Oral 49 Tetrahydrocannabinol in Healthy Young Men. N. Engl. J. Med. 1973, 289, 336-341. [CrossRef]

216. Abboud, R.T.; Sanders, H. Effect of oral administration of Delta9-tetrahydrocannabinol on airway mechanics in normal and asthmatic subjects. Chest 1976, 70, 480-485. [CrossRef]

217. Tashkin, D.P.; Shapiro, B.J.; Lee, Y.E.; Harper, C.E. Effects of smoked marijuana in experimentally induced asthma. Am. Rev. Respir. Dis. 1975, 112, 377-386.

218. Gong, H., Jr.; Tashkin, D.P.; Simmons, M.S.; Calvarese, B.; Shapiro, B.J. Acute and subacute bronchial effects of oral cannabinoids Clin. Pharmacol. Ther. 1984, 35, 26-32. [CrossRef] 
219. Abdallah, S.J.; Smith, B.M.; Ware, M.A.; Moore, M.; Li, P.Z.; Bourbeau, J.; Jensen, D. Effect of Vaporized Cannabis on Exertional Breathlessness and Exercise Endurance in Advanced Chronic Obstructive Pulmonary Disease. A Randomized Controlled Trial. Ann. Am. Thorac. Soc. 2018, 15, 1146-1158. [CrossRef]

220. Bloom, J.W.; Kaltenborn, W.T.; Paoletti, P.; Camilli, A.; Lebowitz, M.D. Respiratory effects of non-tobacco cigarettes. Br. Med. J. (Clin. Res. Ed.) 1987, 295, 1516-1518. [CrossRef]

221. Fligiel, S.E.; Roth, M.D.; Kleerup, E.C.; Barsky, S.H.; Simmons, M.S.; Tashkin, D.P. Tracheobronchial histopathology in habitual smokers of cocaine, marijuana, and/or tobacco. Chest 1997, 112, 319-326. [CrossRef]

222. Cao, D.J.; Aldy, K.; Hsu, S.; McGetrick, M.; Verbeck, G.; De Silva, I.; Feng, S.Y. Review of Health Consequences of Electronic Cigarettes and the Outbreak of Electronic Cigarette, or Vaping, Product Use-Associated Lung Injury. J. Med. Toxicol. 2020, 16, 295-310. [CrossRef] [PubMed]

223. Fantauzzi, M.F.; Cass, S.P.; McGrath, J.J.C.; Thayaparan, D.; Wang, P.; Stampfli, M.R.; Hirota, J.A. Development and validation of a mouse model of contemporary cannabis smoke exposure. ERJ Open Res. 2021, 7. [CrossRef] [PubMed]

224. Tashkin, D.P.; Roth, M.D. Pulmonary effects of inhaled cannabis smoke. Am. J. Drug Alcohol Abus. 2019, 45, 596-609. [CrossRef]

225. Friedman, A.S. Association of vaping-related lung injuries with rates of e-cigarette and cannabis use across US states. Addiction 2021, 116, 651-657. [CrossRef] [PubMed]

226. Wu, H.D.; Wright, R.S.; Sassoon, C.S.; Tashkin, D.P. Effects of smoked marijuana of varying potency on ventilatory drive and metabolic rate. Am. Rev. Respir. Dis. 1992, 146, 716-721. [CrossRef] [PubMed]

227. Stepaniuk, P.; Kanani, A. Selective cannabis strain allergy in a patient presenting with a local allergic reaction. Allergy Asthma Clin. Immunol. 2021, 17, 49. [CrossRef] [PubMed]

228. Mathew, R.J.; Wilson, W.H. Acute changes in cerebral blood flow after smoking marijuana. Life Sci. 1993, 52, 757-767. [CrossRef]

229. Keles, H.O.; Radoman, M.; Pachas, G.N.; Evins, A.E.; Gilman, J.M. Using Functional Near-Infrared Spectroscopy to Measure Effects of Delta 9-Tetrahydrocannabinol on Prefrontal Activity and Working Memory in Cannabis Users. Front. Hum. Neurosci. 2017, 11, 488. [CrossRef] [PubMed]

230. Finch, N.A.; Vilke, G.M. Unknown Tetrahydrocannabinol Edible Ingestion Resulting in Acute Stroke Presentation. J. Emerg. Med. 2020, 58, 296-298. [CrossRef]

231. Wolff, V.; Armspach, J.P.; Beaujeux, R.; Manisor, M.; Rouyer, O.; Lauer, V.; Meyer, N.; Marescaux, C.; Geny, B. High frequency of intracranial arterial stenosis and cannabis use in ischaemic stroke in the young. Cerebrovasc. Dis. 2014, 37, 438-443. [CrossRef] [PubMed]

232. Gómez Ochoa, S.A. Stroke and cannabis use in patients with no cardiovascular risk factors: A systematic review of case reports Neurologia 2021, 36, 222-228. [CrossRef]

233. Hackam, D.G. Cannabis and stroke: Systematic appraisal of case reports. Stroke 2015, 46, 852-856. [CrossRef]

234. Batalla, A.; Bhattacharyya, S.; Yücel, M.; Fusar-Poli, P.; Crippa, J.A.; Nogué, S.; Torrens, M.; Pujol, J.; Farré, M.; Martin-Santos, R. Structural and functional imaging studies in chronic cannabis users: A systematic review of adolescent and adult findings. PLoS ONE 2013, 8, e55821. [CrossRef]

235. Richter, J.S.; Quenardelle, V.; Rouyer, O.; Raul, J.S.; Beaujeux, R.; Gény, B.; Wolff, V. A Systematic Review of the Complex Effects of Cannabinoids on Cerebral and Peripheral Circulation in Animal Models. Front. Physiol. 2018, 9, 622. [CrossRef] [PubMed]

236. Stone, N.L.; England, T.J.; O'Sullivan, S.E. Protective Effects of Cannabidivarin and Cannabigerol on Cells of the Blood-Brain Barrier Under Ischemic Conditions. Cannabis Cannabinoid Res. 2021, 6, 315-326. [CrossRef]

237. Greco, R.; Demartini, C.; Zanaboni, A.; Tumelero, E.; Elisa, C.; Persico, A.; Morotti, A.; Amantea, D.; Tassorelli, C. Characterization of CB2 Receptor Expression in Peripheral Blood Monocytes of Acute Ischemic Stroke Patients. Transl. Stroke Res. 2021, 12, 550-558. [CrossRef]

238. Chiurchiù, V.; Scipioni, L.; Arosio, B.; Mari, D.; Oddi, S.; Maccarrone, M. Anti-Inflammatory Effects of Fatty Acid Amide Hydrolase Inhibition in Monocytes/Macrophages from Alzheimer's Disease Patients. Biomolecules 2021, 11, 502. [CrossRef]

239. Rivas-Santisteban, R.; Lillo, A.; Lillo, J.; Rebassa, J.B.; Contestí, J.S.; Saura, C.A.; Franco, R.; Navarro, G. N-Methyl-D-aspartate (NMDA) and cannabinoid $\mathrm{CB}(2)$ receptors form functional complexes in cells of the central nervous system: Insights into the therapeutic potential of neuronal and microglial NMDA receptors. Alzheimers Res. Ther. 2021, 13, 184. [CrossRef]

240. Franco, R.; Rivas-Santisteban, R.; Casanovas, M.; Lillo, A.; Saura, C.A.; Navarro, G. Adenosine A(2A) Receptor Antagonists Affects NMDA Glutamate Receptor Function. Potential to Address Neurodegeneration in Alzheimer's Disease. Cells 2020, 9 , 1075. [CrossRef] [PubMed]

241. Sideli, L.; Trotta, G.; Spinazzola, E.; La Cascia, C.; Di Forti, M. Adverse effects of heavy cannabis use: Even plants can harm the brain. Pain 2021, 162, S97-S104. [CrossRef]

242. Hall, W.; Degenhardt, L. The adverse health effects of chronic cannabis use. Drug Test. Anal. 2014, 6, 39-45. [CrossRef] [PubMed]

243. Hall, W. What has research over the past two decades revealed about the adverse health effects of recreational cannabis use? Addiction 2015, 110, 19-35. [CrossRef] [PubMed]

244. Wang, Y.; Zuo, C.; Wang, W.; Xu, Q.; Hao, L. Reduction in hippocampal volumes subsequent to heavy cannabis use: A 3-year longitudinal study. Psychiatry Res. 2021, 295, 113588. [CrossRef]

245. Vallée, A.; Vallée, J.N.; Lecarpentier, Y. Potential role of cannabidiol in Parkinson's disease by targeting the WNT/ $\beta$-catenin pathway, oxidative stress and inflammation. Aging 2021, 13, 10796-10813. [CrossRef] [PubMed] 
246. Hepler, R.S.; Frank, I.M.; Ungerleider, J.T. Pupillary constriction after marijuana smoking. Am. J. Ophthalmol. 1972, 74, 1185-1190. [CrossRef]

247. The Cannabinoids $\triangle 8 \mathrm{THC}, \mathrm{CBD}$, and HU-308 Act via Distinct Receptors to Reduce Corneal Pain and Inflammation. Cannabis Cannabinoid Res. 2018, 3, 11-20. [CrossRef]

248. Hsieh, G.C.; Pai, M.; Chandran, P.; Hooker, B.A.; Zhu, C.Z.; Salyers, A.K.; Wensink, E.J.; Zhan, C.; Carroll, W.A.; Dart, M.J.; et al. Central and peripheral sites of action for $\mathrm{CB}_{2}$ receptor mediated analgesic activity in chronic inflammatory and neuropathic pain models in rats. Br. J. Pharmacol. 2011, 162, 428-440. [CrossRef] [PubMed]

249. Vincent, L.; Vang, D.; Nguyen, J.; Benson, B.; Lei, J.; Gupta, K. Cannabinoid receptor-specific mechanisms to alleviate pain in sickle cell anemia via inhibition of mast cell activation and neurogenic inflammation. Haematologica 2016, 101, 566-577. [CrossRef] [PubMed]

250. Barlowe, T.S.; Koliani-Pace, J.L.; Smith, K.D.; Gordon, S.R.; Gardner, T.B. Effects of Medical Cannabis on Use of Opioids and Hospital Visits by Patients With Painful Chronic Pancreatitis. Clin. Gastroenterol. Hepatol. 2019, 17, 2608-2609.e1. [CrossRef]

251. Finn, D.P.; Beckett, S.R.; Roe, C.H.; Madjd, A.; Fone, K.C.; Kendall, D.A.; Marsden, C.A.; Chapman, V. Effects of coadministration of cannabinoids and morphine on nociceptive behaviour, brain monoamines and HPA axis activity in a rat model of persistent pain. Eur. J. Neurosci. 2004, 19, 678-686. [CrossRef] [PubMed]

252. Liang, Y.C.; Huang, C.C.; Hsu, K.S. The synthetic cannabinoids attenuate allodynia and hyperalgesia in a rat model of trigeminal neuropathic pain. Neuropharmacology 2007, 53, 169-177. [CrossRef]

253. Richardson, J.D.; Kilo, S.; Hargreaves, K.M. Cannabinoids reduce hyperalgesia and inflammation via interaction with peripheral CB1 receptors. Pain 1998, 75, 111-119. [CrossRef]

254. Kong, Q.; Tian, S.; Ma, C.; Wang, G.; Zhang, M. Cannabinoid Receptor Type 2 Agonist Reduces Morphine Tolerance via Mitogen Activated Protein Kinase Phosphatase Induction and Mitogen Activated Protein Kinase Dephosphorylation. Neuroscience 2021, 480, 56-64. [CrossRef]

255. Khalid, N.; Singh, A. Cannabis Versus Opioids for Pain. In StatPearls; StatPearls Publishing LLC.: Treasure Island, FL, USA, 2021.

256. Corroon, J.M., Jr.; Mischley, L.K.; Sexton, M. Cannabis as a substitute for prescription drugs-A cross-sectional study. J. Pain Res. 2017, 10, 989-998. [CrossRef] [PubMed]

257. Sepulveda, D.E.; Morris, D.P.; Raup-Konsavage, W.M.; Sun, D.; Vrana, K.E.; Graziane, N.M. Evaluating the Antinociceptive Efficacy of Cannabidiol Alone or in Combination with Morphine Using the Formalin Test in Male and Female Mice. Cannabis Cannabinoid Res. 2021. ahead of print. [CrossRef]

258. Shapiro, L.; Gado, F.; Manera, C.; Escayg, A. Allosteric modulation of the cannabinoid 2 receptor confers seizure resistance in mice. Neuropharmacology 2021, 188, 108448. [CrossRef]

259. Ji, X.; Zeng, Y.; Wu, J. The $\mathrm{CB}_{2}$ Receptor as a Novel Therapeutic Target for Epilepsy Treatment. Int. J. Mol. Sci. $2021,22,8961$. [CrossRef] [PubMed]

260. Shapiro, L.; Wong, J.C.; Escayg, A. Reduced cannabinoid 2 receptor activity increases susceptibility to induced seizures in mice. Epilepsia 2019, 60, 2359-2369. [CrossRef] [PubMed]

261. Jones, N.A.; Hill, A.J.; Smith, I.; Bevan, S.A.; Williams, C.M.; Whalley, B.J.; Stephens, G.J. Cannabidiol Displays Antiepileptiform and Antiseizure Properties In Vitro and In Vivo. J. Pharmacol. Exp. Ther. 2010, 332, 569-577. [CrossRef] [PubMed]

262. Ostrovsky, D.A.; Ehrlich, A. Addition of Cannabidiol to Current Antiepileptic Therapy Reduces Drop Seizures in Children and Adults With Treatment-Resistant Lennox-Gastaut Syndrome. Explore 2018, 14, 311-313. [CrossRef] [PubMed]

263. Klotz, K.A.; Grob, D.; Schönberger, J.; Nakamura, L.; Metternich, B.; Schulze-Bonhage, A.; Jacobs, J. Effect of Cannabidiol on Interictal Epileptiform Activity and Sleep Architecture in Children with Intractable Epilepsy: A Prospective Open-Label Study. CNS Drugs 2021, 35, 1207-1215. [CrossRef]

264. Patra, P.H.; Barker-Haliski, M.; White, H.S.; Whalley, B.J.; Glyn, S.; Sandhu, H.; Jones, N.; Bazelot, M.; Williams, C.M.; McNeish, A.J. Cannabidiol reduces seizures and associated behavioral comorbidities in a range of animal seizure and epilepsy models. Epilepsia 2019, 60, 303-314. [CrossRef] [PubMed]

265. Löscher, W. Animal models of epilepsy for the development of antiepileptogenic and disease-modifying drugs. A comparison of the pharmacology of kindling and post-status epilepticus models of temporal lobe epilepsy. Epilepsy Res. 2002, 50, 105-123. [CrossRef]

266. Gaston, T.E.; Martin, R.C.; Szaflarski, J.P. Cannabidiol (CBD) and cognition in epilepsy. Epilepsy Behav. 2021, $124,108316$. [CrossRef]

267. Anderson, L.L.; Heblinski, M.; Absalom, N.L.; Hawkins, N.A.; Bowen, M.T.; Benson, M.J.; Zhang, F.; Bahceci, D.; Doohan, P.T.; Chebib, M.; et al. Cannabigerolic acid, a major biosynthetic precursor molecule in cannabis, exhibits divergent effects on seizures in mouse models of epilepsy. Br. J. Pharmacol. 2021, 178, 4826-4841. [CrossRef]

268. Nowicki, M.; Bourgeois-Tardif, S.; Diaz, P.L.; Hebert, F.O.; Sanon, N.T.; Champagne, P.O.; Major, P.; Sell, E.; Bitton, J.; Lewis, E.; et al. Potential Benefit of Add-on $\Delta$ 9-Tetrahydrocannabinol in Pediatric Drug-Resistant Epilepsy: A Case Series. Can. J. Neurol. Sci 2021, 1-3. [CrossRef] [PubMed]

269. Huntsman, R.J.; Tang-Wai, R.; Alcorn, J.; Vuong, S.; Acton, B.; Corley, S.; Laprairie, R.; Lyon, A.W.; Meier, S.; Mousseau, D.D.; et al. Dosage Related Efficacy and Tolerability of Cannabidiol in Children With Treatment-Resistant Epileptic Encephalopathy: Preliminary Results of the CARE-E Study. Front. Neurol. 2019, 10, 716. [CrossRef] [PubMed] 
270. Patel, S.; Grinspoon, R.; Fleming, B.; Skirvin, L.A.; Wade, C.; Wolper, E.; Bruno, P.L.; Thiele, E.A. The long-term efficacy of cannabidiol in the treatment of refractory epilepsy. Epilepsia 2021, 62, 1594-1603. [CrossRef] [PubMed]

271. Marchese, F.; Vari, M.S.; Balagura, G.; Riva, A.; Salpietro, V.; Verrotti, A.; Citraro, R.; Lattanzi, S.; Minetti, C.; Russo, E.; et al. An Open Retrospective Study of a Standardized Cannabidiol Based-Oil in Treatment-Resistant Epilepsy. Cannabis Cannabinoid Res. 2020. ahead of print. [CrossRef] [PubMed]

272. Farrelly, A.M.; Vlachou, S.; Grintzalis, K. Efficacy of Phytocannabinoids in Epilepsy Treatment: Novel Approaches and Recent Advances. Int. J. Environ. Res. Public Health 2021, 18, 3993. [CrossRef] [PubMed]

273. Oleson, E.B.; Hamilton, L.R.; Gomez, D.M. Cannabinoid Modulation of Dopamine Release During Motivation, Periodic Reinforcement, Exploratory Behavior, Habit Formation, and Attention. Front. Synaptic Neurosci. 2021, 13, 660218. [CrossRef]

274. Zangen, A.; Solinas, M.; Ikemoto, S.; Goldberg, S.R.; Wise, R.A. Two brain sites for cannabinoid reward. J. Neurosci. 2006, 26, 4901-4907. [CrossRef] [PubMed]

275. Spiller, K.J.; Bi, G.H.; He, Y.; Galaj, E.; Gardner, E.L.; Xi, Z.X. Cannabinoid $\mathrm{CB}_{1}$ and $\mathrm{CB}_{2}$ receptor mechanisms underlie cannabis reward and aversion in rats. Br. J. Pharmacol. 2019, 176, 1268-1281. [CrossRef]

276. Ronen, A.; Chassidim, H.S.; Gershon, P.; Parmet, Y.; Rabinovich, A.; Bar-Hamburger, R.; Cassuto, Y.; Shinar, D. The effect of alcohol, THC and their combination on perceived effects, willingness to drive and performance of driving and non-driving tasks. Accid. Anal. Prev. 2010, 42, 1855-1865. [CrossRef]

277. Andréasson, S.; Allebeck, P.; Engström, A.; Rydberg, U. Cannabis and schizophrenia. A longitudinal study of Swedish conscripts. Lancet 1987, 2, 1483-1486. [CrossRef]

278. Carlini, E.A.; Cunha, J.M. Hypnotic and antiepileptic effects of cannabidiol. J. Clin. Pharmacol. 1981, 21, 417S-427S. [CrossRef]

279. Wilkinson, S.T.; Stefanovics, E.; Rosenheck, R.A. Marijuana use is associated with worse outcomes in symptom severity and violent behavior in patients with posttraumatic stress disorder. J. Clin. Psychiatry 2015, 76, 1174-1180. [CrossRef]

280. Benowitz, N.L.; Jones, R.T. Effects of delta-9-tetrahydrocannabinol on drug distribution and metabolism. Antipyrine, pentobarbital, and ethanol. Clin. Pharmacol. Ther. 1977, 22, 259-268. [CrossRef] [PubMed]

281. Drennan, M.L.; Karoly, H.C.; Bryan, A.D.; Hutchison, K.E.; Bidwell, L.C. Acute objective and subjective intoxication effects of legal-market high potency THC-dominant versus CBD-dominant cannabis concentrates. Sci. Rep. 2021, 11, 21744. [CrossRef] [PubMed]

282. El-Yousef, M.K.; Janowsky, D.S.; Davis, J.M.; Rosenblatt, J.E. Induction of severe depression by physostigmine in marijuana intoxicated individuals. Br. J. Addict. Alcohol Other Drugs 1973, 68, 321-325. [CrossRef]

283. Maldonado, R.; Berrendero, F.; Ozaita, A.; Robledo, P. Neurochemical basis of cannabis addiction. Neuroscience 2011, 181, 1-17. [CrossRef]

284. Livne, O.; Shmulewitz, D.; Lev-Ran, S.; Hasin, D.S. DSM-5 cannabis withdrawal syndrome: Demographic and clinical correlates in U.S. adults. Drug Alcohol Depend. 2019, 195, 170-177. [CrossRef] [PubMed]

285. Gorelick, D.A.; Levin, K.H.; Copersino, M.L.; Heishman, S.J.; Liu, F.; Boggs, D.L.; Kelly, D.L. Diagnostic criteria for cannabis withdrawal syndrome. Drug Alcohol Depend. 2012, 123, 141-147. [CrossRef]

286. Preuss, U.W.; Watzke, A.B.; Zimmermann, J.; Wong, J.W.; Schmidt, C.O. Cannabis withdrawal severity and short-term course among cannabis-dependent adolescent and young adult inpatients. Drug Alcohol Depend. 2010, 106, 133-141. [CrossRef]

287. Bonnet, U.; Preuss, U.W. The cannabis withdrawal syndrome: Current insights. Subst. Abus. Rehabil. 2017, 8, 9-37. [CrossRef]

288. Bahji, A.; Stephenson, C.; Tyo, R.; Hawken, E.R.; Seitz, D.P. Prevalence of Cannabis Withdrawal Symptoms Among People With Regular or Dependent Use of Cannabinoids: A Systematic Review and Meta-analysis. JAMA Netw. Open 2020, 3, e202370. [CrossRef] [PubMed]

289. MacCamy, K.; Hu, D. Dexmedetomidine for Treatment of Delayed Peak Symptoms of Cannabis Withdrawal Syndrome: A Case Report. Hosp. Pharm. 2021, 56, 462-465. [CrossRef]

290. Brantl, S.A.; Khandoga, A.L.; Siess, W. Mechanism of platelet activation induced by endocannabinoids in blood and plasma. Platelets 2014, 25, 151-161. [CrossRef]

291. Brantl, S.A.; Khandoga, A.L.; Siess, W. Activation of platelets by the endocannabinoids 2-arachidonoylglycerol and virodhamine is mediated by their conversion to arachidonic acid and thromboxane A2, not by activation of cannabinoid receptors. Platelets 2014, 25, 465-466. [CrossRef] [PubMed]

292. Keown, O.P.; Winterburn, T.J.; Wainwright, C.L.; Macrury, S.M.; Neilson, I.; Barrett, F.; Leslie, S.J.; Megson, I.L. 2-arachidonyl glycerol activates platelets via conversion to arachidonic acid and not by direct activation of cannabinoid receptors. Br. J. Clin. Pharmacol. 2010, 70, 180-188. [CrossRef] [PubMed]

293. Berdyshev, E.V.; Schmid, P.C.; Krebsbach, R.J.; Schmid, H.H. Activation of PAF receptors results in enhanced synthesis of 2-arachidonoylglycerol (2-AG) in immune cells. FASEB J. 2001, 15, 2171-2178. [CrossRef]

294. Grambow, E.; Strüder, D.; Klar, E.; Hinz, B.; Vollmar, B. Differential effects of endogenous, phyto and synthetic cannabinoids on thrombogenesis and platelet activity. Biofactors 2016, 42, 581-590. [CrossRef] [PubMed]

295. Huff, H.C.; Vasan, A.; Roy, P.; Kaul, A.; Tajkhorshid, E.; Das, A. Differential Interactions of Selected Phytocannabinoids with Human CYP2D6 Polymorphisms. Biochemistry 2021, 60, 2749-2760. [CrossRef] [PubMed]

296. Yamaori, S.; Koeda, K.; Kushihara, M.; Hada, Y.; Yamamoto, I.; Watanabe, K. Comparison in the in vitro inhibitory effects of major phytocannabinoids and polycyclic aromatic hydrocarbons contained in marijuana smoke on cytochrome P450 2C9 activity. Drug Metab. Pharmacokinet. 2012, 27, 294-300. [CrossRef] [PubMed] 
297. Yamaori, S.; Ebisawa, J.; Okushima, Y.; Yamamoto, I.; Watanabe, K. Potent inhibition of human cytochrome P450 3A isoforms by cannabidiol: Role of phenolic hydroxyl groups in the resorcinol moiety. Life Sci. 2011, 88, 730-736. [CrossRef]

298. Wang, S.; Zhu, Q.; Liang, G.; Franks, T.; Boucher, M.; Bence, K.K.; Lu, M.; Castorena, C.M.; Zhao, S.; Elmquist, J.K.; et al. Cannabinoid receptor 1 signaling in hepatocytes and stellate cells does not contribute to NAFLD. J. Clin. Investig. 2021, 131, e152242. [CrossRef]

299. Yang, K.; Choi, S.E.; Jeong, W.I. Hepatic Cannabinoid Signaling in the Regulation of Alcohol-Associated Liver Disease. Alcohol Res. Curr. Rev. 2021, 41, 12. [CrossRef]

300. Nasrin, S.; Watson, C.J.W.; Perez-Paramo, Y.X.; Lazarus, P. Cannabinoid Metabolites as Inhibitors of Major Hepatic CYP450 Enzymes, with Implications for Cannabis-Drug Interactions. Drug Metab. Dispos. Biol. Fate Chem. 2021, 49, 1070-1080. [CrossRef]

301. Sahinovic, M.M.; Struys, M.; Absalom, A.R. Clinical Pharmacokinetics and Pharmacodynamics of Propofol. Clin. Pharmacokinet. 2018, 57, 1539-1558. [CrossRef] [PubMed]

302. Dinis-Oliveira, R.J. Metabolism and metabolomics of ketamine: A toxicological approach. Forensic Sci. Res. 2017, 2, 2-10. [CrossRef] [PubMed]

303. Balachandran, P.; Elsohly, M.; Hill, K.P. Cannabidiol Interactions with Medications, Illicit Substances, and Alcohol: A Comprehensive Review. J. Gen. Intern. Med. 2021, 36, 2074-2084. [CrossRef]

304. Stout, S.M.; Cimino, N.M. Exogenous cannabinoids as substrates, inhibitors, and inducers of human drug metabolizing enzymes: A systematic review. Drug Metab. Rev. 2014, 46, 86-95. [CrossRef] [PubMed]

305. Bland, T.M.; Haining, R.L.; Tracy, T.S.; Callery, P.S. CYP2C-catalyzed delta9-tetrahydrocannabinol metabolism: Kinetics, pharmacogenetics and interaction with phenytoin. Biochem. Pharmacol. 2005, 70, 1096-1103. [CrossRef]

306. Anzenbacherova, E.; Spicakova, A.; Jourova, L.; Ulrichova, J.; Adamus, M.; Bachleda, P.; Anzenbacher, P. Interaction of rocuronium with human liver cytochromes P450. J. Pharmacol. Sci. 2015, 127, 190-195. [CrossRef]

307. Sweeney, B.P.; Bromilow, J. Liver enzyme induction and inhibition: Implications for anaesthesia. Anaesthesia 2006, 61, 159-177. [CrossRef] [PubMed]

308. Restrepo, J.G.; Garcia-Martín, E.; Martínez, C.; Agúndez, J.A. Polymorphic drug metabolism in anaesthesia. Curr. Drug Metab. 2009, 10, 236-246. [CrossRef] [PubMed]

309. Qian, Y.; Gurley, B.J.; Markowitz, J.S. The Potential for Pharmacokinetic Interactions Between Cannabis Products and Conventional Medications. J. Clin. Psychopharmacol. 2019, 39, 462-471. [CrossRef]

310. Wandel, C.; Böcker, R.; Böhrer, H.; Browne, A.; Rügheimer, E.; Martin, E. Midazolam is metabolized by at least three different cytochrome P450 enzymes. Br. J. Anaesth. 1994, 73, 658-661. [CrossRef]

311. Dean, L. Diazepam Therapy and CYP2C19 Genotype. In Medical Genetics Summaries; Pratt, V.M.S.S., Pirmohamed, M., Eds.; National Center for Biotechnology Information: Bethesda, MD, USA, 2020.

312. Wilde, M.; Pichini, S.; Pacifici, R.; Tagliabracci, A.; Busardò, F.P.; Auwärter, V.; Solimini, R. Metabolic Pathways and Potencies of New Fentanyl Analogs. Front. Pharmacol. 2019, 10, 238. [CrossRef] [PubMed]

313. Vázquez, M.; Guevara, N.; Maldonado, C.; Guido, P.C.; Schaiquevich, P. Potential Pharmacokinetic Drug-Drug Interactions between Cannabinoids and Drugs Used for Chronic Pain. Biomed. Res. Int. 2020, 2020, 3902740. [CrossRef]

314. Laine, J.E.; Auriola, S.; Pasanen, M.; Juvonen, R.O. Acetaminophen bioactivation by human cytochrome P450 enzymes and animal microsomes. Xenobiotica 2009, 39, 11-21. [CrossRef]

315. Gertler, R.; Brown, H.C.; Mitchell, D.H.; Silvius, E.N. Dexmedetomidine: A novel sedative-analgesic agent. Bayl. Univ. Med. Cent. Proc. 2001, 14, 13-21. [CrossRef]

316. Long, T.; Cristofoletti, R.; Cicali, B.; Michaud, V.; Dow, P.; Turgeon, J.; Schmidt, S. Physiologically Based Pharmacokinetic Modeling to Assess the Impact of CYP2D6-Mediated Drug-Drug Interactions on Tramadol and O-Desmethyltramadol Exposures via Allosteric and Competitive Inhibition. J. Clin. Pharmacol. 2022, 62, 76-86. [CrossRef]

317. Kirchheiner, J.; Schmidt, H.; Tzvetkov, M.; Keulen, J.T.; Lötsch, J.; Roots, I.; Brockmöller, J. Pharmacokinetics of codeine and its metabolite morphine in ultra-rapid metabolizers due to CYP2D6 duplication. Pharm. J. 2007, 7, 257-265. [CrossRef] [PubMed]

318. Michalets, E.L. Update: Clinically significant cytochrome P-450 drug interactions. Pharmacotherapy 1998, 18, 84-112. [PubMed]

319. Silva, R.L.; Silveira, G.T.; Wanderlei, C.W.; Cecilio, N.T.; Maganin, A.G.M.; Franchin, M.; Marques, L.M.M.; Lopes, N.P.; Crippa, J.A.; Guimarães, F.S.; et al. DMH-CBD, a cannabidiol analog with reduced cytotoxicity, inhibits TNF production by targeting NF-kB activity dependent on A(2A) receptor. Toxicol. Appl. Pharmacol. 2019, 368, 63-71. [CrossRef]

320. Alasmari, F.; Alsanea, S.; Alfadda, A.A.; Alanazi, I.O.; Musambil, M.; Masood, A.; Alqahtani, F.; Fantoukh, O.I.; Alasmari, A.F.; Benabdelkamel, H. Serum Proteomic Analysis of Cannabis Use Disorder in Male Patients. Molecules 2021, 26, 5311. [CrossRef] [PubMed]

321. Ward, J.R.; West, P.W.; Ariaans, M.P.; Parker, L.C.; Francis, S.E.; Crossman, D.C.; Sabroe, I.; Wilson, H.L. Temporal interleukin-1beta secretion from primary human peripheral blood monocytes by P2X7-independent and P2X7-dependent mechanisms. J. Biol. Chem. 2010, 285, 23147-23158. [CrossRef] [PubMed]

322. Liu, C.; Ma, H.; Slitt, A.L.; Seeram, N.P. Inhibitory Effect of Cannabidiol on the Activation of NLRP3 Inflammasome Is Associated with Its Modulation of the P2X7 Receptor in Human Monocytes. J. Nat. Prod. 2020, 83, 2025-2029. [CrossRef]

323. Rizzo, M.D.; Crawford, R.B.; Bach, A.; Sermet, S.; Amalfitano, A.; Kaminski, N.E. $\Delta^{9}$-Tetrahydrocannabinol Suppresses MonocyteMediated Astrocyte Production of Monocyte Chemoattractant Protein 1 and Interleukin-6 in a Toll-Like Receptor 7-Stimulated Human Coculture. J. Pharmacol. Exp. Ther. 2019, 371, 191-201. [CrossRef] [PubMed] 
324. Karmaus, P.W.; Chen, W.; Crawford, R.; Kaplan, B.L.; Kaminski, N.E. $\Delta$ 9-tetrahydrocannabinol impairs the inflammatory response to influenza infection: Role of antigen-presenting cells and the cannabinoid receptors 1 and 2. Toxicol. Sci. 2013, 131, 419-433. [CrossRef]

325. Massimini, M.; Dalle Vedove, E.; Bachetti, B.; Di Pierro, F.; Ribecco, C.; D’Addario, C.; Pucci, M. Polyphenols and Cannabidiol Modulate Transcriptional Regulation of Th1/Th2 Inflammatory Genes Related to Canine Atopic Dermatitis. Front. Vet. Sci. 2021, 8, 606197. [CrossRef]

326. Ignatowska-Jankowska, B.; Jankowski, M.; Glac, W.; Swiergel, A.H. Cannabidiol-induced lymphopenia does not involve NKT and NK cells. J. Physiol. Pharmacol. 2009, 60 (Suppl. 3), 99-103.

327. Sermet, S.; Li, J.; Bach, A.; Crawford, R.B.; Kaminski, N.E. Cannabidiol selectively modulates interleukin (IL)-1 $\beta$ and IL-6 production in toll-like receptor activated human peripheral blood monocytes. Toxicology 2021, 464, 153016. [CrossRef]

328. Muthumalage, T.; Rahman, I. Cannabidiol differentially regulates basal and LPS-induced inflammatory responses in macrophages, lung epithelial cells, and fibroblasts. Toxicol. Appl. Pharmacol. 2019, 382, 114713. [CrossRef]

329. Henriquez, J.E.; Crawford, R.B.; Kaminski, N.E. Suppression of CpG-ODN-mediated IFN $\alpha$ and TNF $\alpha$ response in human plasmacytoid dendritic cells (pDC) by cannabinoid receptor 2 (CB2)-specific agonists. Toxicol. Appl. Pharmacol. 2019, 369, 82-89. [CrossRef]

330. Henriquez, J.E.; Bach, A.P.; Matos-Fernandez, K.M.; Crawford, R.B.; Kaminski, N.E. $\Delta^{9}$-Tetrahydrocannabinol (THC) Impairs CD8 ${ }^{+}$T Cell-Mediated Activation of Astrocytes. J. Neuroimmune Pharmacol. 2020, 15, 863-874. [CrossRef]

331. Lee, K.M.; Renne, R.A.; Harbo, S.J.; Clark, M.L.; Johnson, R.E.; Gideon, K.M. 3-week inhalation exposure to cigarette smoke and/or lipopolysaccharide in AKR/J mice. Inhal. Toxicol. 2007, 19, 23-35. [CrossRef] [PubMed]

332. Yeisley, D.J.; Arabiyat, A.S.; Hahn, M.S. Cannabidiol-Driven Alterations to Inflammatory Protein Landscape of LipopolysaccharideActivated Macrophages In Vitro May Be Mediated by Autophagy and Oxidative Stress. Cannabis Cannabinoid Res. 2021, 6, 253-263. [CrossRef]

333. Lu, T.; Newton, C.; Perkins, I.; Friedman, H.; Klein, T.W. Role of cannabinoid receptors in Delta-9-tetrahydrocannabinol suppression of IL-12p40 in mouse bone marrow-derived dendritic cells infected with Legionella pneumophila. Eur. J. Pharmacol. 2006, 532, 170-177. [CrossRef] [PubMed]

334. Rizzo, M.D.; Henriquez, J.E.; Blevins, L.K.; Bach, A.; Crawford, R.B.; Kaminski, N.E. Targeting Cannabinoid Receptor 2 on Peripheral Leukocytes to Attenuate Inflammatory Mechanisms Implicated in HIV-Associated Neurocognitive Disorder. J. Neuroimmune Pharmacol. 2020, 15, 780-793. [CrossRef]

335. Purohit, V.; Rapaka, R.S.; Rutter, J. Cannabinoid receptor-2 and HIV-associated neurocognitive disorders. J. Neuroimmune Pharmacol. 2014, 9, 447-453. [CrossRef] [PubMed]

336. Xiong, Y.; Lim, C.S. Understanding the Modulatory Effects of Cannabidiol on Alzheimer's Disease. Brain Sci. $2021,11,1211$. [CrossRef]

337. Kelly, B.F.; Nappe, T.M. Cannabinoid Toxicity. In StatPearls; StatPearls Publishing LLC.: Treasure Island, FL, USA, 2021.

338. Forney, R.B. Toxicology of marihuana. Pharmacol. Rev. 1971, 23, 279-284.

339. Courts, J.; Maskill, V.; Gray, A.; Glue, P. Signs and symptoms associated with synthetic cannabinoid toxicity: Systematic review. Australas. Psychiatry Bull. R. Aust. N. Z. Coll. Psychiatr. 2016, 24, 598-601. [CrossRef]

340. Hoffman, M.A.; Hubbard, J.A.; Sobolesky, P.M.; Smith, B.E.; Suhandynata, R.T.; Sanford, S.; Sones, E.G.; Ellis, S.; Umlauf, A.; Huestis, M.A.; et al. Blood and Oral Fluid Cannabinoid Profiles of Frequent and Occasional Cannabis Smokers. J. Anal. Toxicol. 2021, 45, 851-862. [CrossRef] [PubMed]

341. Desrosiers, N.A.; Himes, S.K.; Scheidweiler, K.B.; Concheiro-Guisan, M.; Gorelick, D.A.; Huestis, M.A. Phase I and II cannabinoid disposition in blood and plasma of occasional and frequent smokers following controlled smoked cannabis. Clin. Chem. 2014, 60, 631-643. [CrossRef]

342. Newmeyer, M.N.; Swortwood, M.J.; Barnes, A.J.; Abulseoud, O.A.; Scheidweiler, K.B.; Huestis, M.A. Free and Glucuronide Whole Blood Cannabinoids' Pharmacokinetics after Controlled Smoked, Vaporized, and Oral Cannabis Administration in Frequent and Occasional Cannabis Users: Identification of Recent Cannabis Intake. Clin. Chem. 2016, 62, 1579-1592. [CrossRef] [PubMed]

343. Sun, S.; Zimmermann, A.E. Cannabinoid hyperemesis syndrome. Hosp. Pharm. 2013, 48, 650-655. [CrossRef] [PubMed]

344. Asbridge, M.; Hayden, J.A.; Cartwright, J.L. Acute cannabis consumption and motor vehicle collision risk: Systematic review of observational studies and meta-analysis. BMJ 2012, 344, e536. [CrossRef]

345. McCartney, D.; Arkell, T.R.; Irwin, C.; McGregor, I.S. Determining the magnitude and duration of acute $\Delta^{9}$-tetrahydrocannabinol $\left(\Delta^{9}-\mathrm{THC}\right)$-induced driving and cognitive impairment: A systematic and meta-analytic review. Neurosci. Biobehav. Rev. 2021, 126, 175-193. [CrossRef]

346. WEINBERG, D.; LANDE, A.; Hilton, N.; KERNS, D.L. Intoxication from accidental marijuana ingestion. Pediatrics 1983, 71, 848-850. [CrossRef]

347. Iftikhar, S.; Jamil, A.; Savoj, J.; Gulati, R. Marijuana induced coronary vasospasm. Curr. Trends Intern. Med. 2018, 103, 10. [CrossRef]

348. Sadighi, T.; Londahl-Ramsey, V. Cannabis Use: Change in Screening for Primary Care Preoperative Clearance. J. Nurse Pract. 2021, 17, 819-822. [CrossRef]

349. Miller, R.J.; Gerhardt, M.A. Uvular Edema Secondary to Snoring Under Deep Sedation. Anesth. Prog. 2006, 53, 13-16. [CrossRef]

350. Rawal, S.Y.; Tatakis, D.N.; Tipton, D.A. Periodontal and oral manifestations of marijuana use. J. Tenn. Dent. Assoc. 2012, 92, 26. 
351. Le, A.; Palamar, J.J. Oral health implications of increased cannabis use among older adults: Another public health concern? J. Subst. Use 2019, 24, 61-65. [CrossRef] [PubMed]

352. Mallat, A.; Roberson, J.; Brock-Utne, J.G. Preoperative marijuana inhalation-An airway concern. Can. J. Anaesth. 1996, 43, 691-693. [CrossRef] [PubMed]

353. Flisberg, P.; Paech, M.; Shah, T.; Ledowski, T.; Kurowski, I.; Parsons, R. Induction dose of propofol in patients using cannabis. Eur. J. Anaesthesiol. 2009, 26, 192-195. [CrossRef]

354. Frizza, J.; Chesher, G.; Jackson, D.; Malor, R.; Starmer, G. The effect of $\Delta^{9}$, cannabidiol, and cannabinol on the anaesthesia induced by various anaesthetic agents in mice. Psychopharmacology 1977, 55, 103-107. [CrossRef] [PubMed]

355. Chesher, G.B.; Jackson, D.M.; Starmer, G.A. Interaction of cannabis and general anaesthetic agents in mice. Br. J. Pharmacol. 1974, 50, 593-599. [CrossRef]

356. Orden, C.; Santos, M.; Ceprian, M.; Tendillo, F.J. The effect of cannabidiol on sevoflurane minimum alveolar concentration reduction produced by morphine in rats. Vet. Anaesth. Analg. 2021, 48, 74-81. [CrossRef]

357. Müller, J.; Plöchl, W.; Reiter, B.; Stimpfl, T.; Graf, A.; Baron-Stefaniak, J.; Infanger, L.; Hamp, T. The effect of oral $\Delta-9-$ tetrahydrocannabinol on the minimal alveolar concentration of sevoflurane: A randomised, controlled, observer-blinded experimental study. Eur. J. Anaesthesiol. 2021, 38, 58-63. [CrossRef] [PubMed]

358. Ibera, C.; Shalom, B.; Saifi, F.; Shruder, J.; Davidson, E. Effects of Cannabis Extract Premedication On Anesthetic Depth. Harefuah 2018, 157, 162-166.

359. Uhing, M.R.; Beno, D.W.; Jiyamapa-Serna, V.A.; Chen, Y.; Galinsky, R.E.; Hall, S.D.; Kimura, R.E. The effect of anesthesia and surgery on CYP3A activity in rats. Drug Metab. Dispos. Biol. Fate Chem. 2004, 32, 1325-1330. [CrossRef]

360. Cossu, A.E.; Latham, L.B.; Hardacker, D.M.; Jea, A.H. Pharmacologic chaos: Severe hypotension from interactions of anesthetics, marijuana, amphetamines, and paroxetine. J. Clin. Anesth. 2019, 55, 17. [CrossRef]

361. Benowitz, N.L.; Jones, R.T. Cardiovascular effects of prolonged delta-9-tetrahydrocannabinol ingestion. Clin. Pharmacol. Ther. 1975, 18, 287-297. [CrossRef] [PubMed]

362. Johnson, S.; Domino, E.F. Some cardiovascular effects of marihuana smoking in normal volunteers. Clin. Pharmacol. Ther. 1971, 12, 762-768. [CrossRef] [PubMed]

363. Jouanjus, E.; Raymond, V.; Lapeyre-Mestre, M.; Wolff, V. What is the Current Knowledge About the Cardiovascular Risk for Users of Cannabis-Based Products? A Systematic Review. Curr. Atheroscler. Rep. 2017, 19, 26. [CrossRef] [PubMed]

364. Desai, R.; Patel, U.; Deshmukh, A.; Sachdeva, R.; Kumar, G. Burden of arrhythmia in recreational marijuana users. Int. J. Cardiol. 2018, 264, 91-92. [CrossRef]

365. Sankar-Maharaj, S.; Chen, D.; Hariharan, S. Postoperative shivering among cannabis users at a public hospital in Trinidad, West Indies. J. PeriAnesthesia Nurs. 2018, 33, 37-44. [CrossRef]

366. Thayer, A.; Murataeva, N.; Delcroix, V.; Wager-Miller, J.; Makarenkova, H.P.; Straiker, A. THC Regulates Tearing via Cannabinoid CB1 Receptors. Investig. Ophthalmol. Vis. Sci. 2020, 61, 48. [CrossRef]

367. Buggy, D.J.; Toogood, L.; Maric, S.; Sharpe, P.; Lambert, D.G.; Rowbotham, D.J. Lack of analgesic efficacy of oral delta-9tetrahydrocannabinol in postoperative pain. Pain 2003, 106, 169-172. [CrossRef]

368. Beaulieu, P. Effects of nabilone, a synthetic cannabinoid, on postoperative pain. Can. J. Anaesth. 2006, 53, 769-775. [CrossRef]

369. Holdcroft, A.; Maze, M.; Dore, C.; Tebbs, S.; Thompson, S. A multicenter dose-escalation study of the analgesic and adverse effects of an oral cannabis extract (Cannador) for postoperative pain management. Anesthesiology 2006, 104, 1040-1046. [CrossRef] [PubMed]

370. Ewing, L.E.; McGill, M.R.; Yee, E.U.; Quick, C.M.; Skinner, C.M.; Kennon-McGill, S.; Clemens, M.; Vazquez, J.H.; McCullough, S.S.; Williams, D.K.; et al. Paradoxical Patterns of Sinusoidal Obstruction Syndrome-Like Liver Injury in Aged Female CD-1 Mice Triggered by Cannabidiol-Rich Cannabis Extract and Acetaminophen Co-Administration. Molecules 2019, 24, 2256. [CrossRef] [PubMed]

371. Burton, T.A. Urinary retention following cannabis ingestion. JAMA 1979, 242, 351. [CrossRef] [PubMed]

372. Zhang, B.H.; Saud, H.; Sengupta, N.; Chen, M.; Bakshi, D.; Richardson, L.; Wang, L.; Shanthanna, H. Effect of preoperative cannabis use on perioperative outcomes: A retrospective cohort study. Reg. Anesth. Pain Med. 2021, 46, 650-655. [CrossRef] [PubMed]

373. Goel, A.; McGuinness, B.; Jivraj, N.K.; Wijeysundera, D.N.; Mittleman, M.A.; Bateman, B.T.; Clarke, H.; Kotra, L.P.; Ladha, K.S. Cannabis Use Disorder and Perioperative Outcomes in Major Elective Surgeries: A Retrospective Cohort Analysis. Anesthesiology 2020, 132, 625-635. [CrossRef] [PubMed] 